\title{
Effects of 3-nitrooxypropanol on rumen fermentation, lactational performance, and resumption of ovarian cyclicity in dairy cows
}

\author{
A. Melgar, ${ }^{1}$ M. T. Harper, ${ }^{1}$ J. Oh, ${ }^{1}$ F. Giallongo, ${ }^{1}$ M. E. Young, ${ }^{1}$ T. L. Ott, ${ }^{1}$ S. Duval, ${ }^{2}$ and A. N. Hristov ${ }^{1 *}$ \\ ${ }^{1}$ Department of Animal Science, The Pennsylvania State University, University Park 16802 \\ ${ }^{2}$ Research Centre for Animal Nutrition and Health, DSM Nutritional Products, Saint Louis Cedex 68305, France
}

\begin{abstract}
This study examined the effect of 3-nitrooxypropanol (3-NOP), a substance under investigation, on enteric methane $\left(\mathrm{CH}_{4}\right)$ emission, rumen fermentation, lactational performance, sensory properties of milk, and the resumption of ovarian cyclicity in early-lactation dairy cows. Fifty-six multi- and primiparous Holstein cows, including 8 that were rumen cannulated, were used in a 15-wk randomized complete block design experiment. Cows were blocked based on parity and previous lactation milk yield (MY) or predicted MY, and within each block were randomly assigned to one of 2 treatments: (1) control (CON), administered no 3-NOP, or (2) 3-NOP applied at $60 \mathrm{mg} / \mathrm{kg}$ of feed dry matter (3-NOP). Enteric $\mathrm{CH}_{4}$ emission was measured during experimental wk 2, 6, 9, and 15, using the GreenFeed system. Dry matter intake (DMI) and MY data were collected daily throughout the experiment, and milk composition samples were collected 7 times during the experiment. Milk samples were collected from 14 to $60( \pm 2) \mathrm{d}$ after calving, $3 \mathrm{~d}$ per week, and assayed for progesterone concentration to determine resumption of ovarian activity. Compared with CON, 3-NOP decreased daily $\mathrm{CH}_{4}$ emission by $26 \%, \mathrm{CH}_{4}$ yield $\left(\mathrm{CH}_{4}\right.$ per $\mathrm{kg}$ of DMI) by $21 \%$, and $\mathrm{CH}_{4}$ emission intensity $\left[\mathrm{CH}_{4}\right.$ per kg of MY or energy-corrected milk (ECM)] by $25 \%$. Enteric emission of carbon dioxide was decreased by $5 \%$, and hydrogen emission was increased 48 -fold by 3 -NOP. Inclusion of 3-NOP decreased concentration of total volatile fatty acids (by $9.3 \%$ ) and acetate but increased butyrate molar proportion, ethanol, and formate concentrations in ruminal fluid. Dry matter intake was lower for 3-NOP compared with CON, but DMI expressed as a percentage of body weight was not different between treatments. Treatment had no effect on milk and ECM, body weight change, or body condition score. Milk composition and milk fat and protein yields
\end{abstract}

\footnotetext{
Received June 9, 2019.

Accepted September 18, 2019.

*Corresponding author: anh13@psu.edu
}

were not affected by treatment, except that concentrations of short-chain fatty acids in milk were increased by 3 -NOP. Nutrient digestibility and blood metabolites and hormones were not affected by 3 -NOP, except that insulin was decreased by 3 -NOP. There was no effect of 3 -NOP on postpartum resumption of ovarian activity, including days to first and second luteal phases, length of first and second luteal phases, and interval from first to second luteal phase. Sensory properties of milk from cows fed 3-NOP and cheese made from that milk were not affected by treatment. In this experiment, 3-NOP decreased daily enteric $\mathrm{CH}_{4}$ emission, emission yield, and emission intensity, improved feed efficiency, and did not affect lactational performance or onset of ovarian activity in early-lactation dairy cows.

Key words: methane, 3-nitrooxypropanol, dairy cattle, feed efficiency, reproduction

\section{INTRODUCTION}

Enteric methane $\left(\mathrm{CH}_{4}\right)$ is a natural product of the anaerobic fermentation of $\mathrm{OM}$ in the rumen. Methanogenesis involves a consortium of rumen microorganisms, with the final step carried out by methanogenic archaea that utilize carbon dioxide $\left(\mathrm{CO}_{2}\right)$ and hydrogen $\left(\mathrm{H}_{2}\right)$ as primary energy substrates (Wolin, 1981). Both $\mathrm{CO}_{2}$ and $\mathrm{H}_{2}$ are by-products of the fermentation of plant material and subsequent synthesis of VFA in the rumen. Volatile fatty acid synthesis accounts for $75 \%$ of the energy content of carbohydrates, with the remaining $25 \%$ being used for microbial growth or lost as $\mathrm{H}_{2}$ and $\mathrm{CH}_{4}$ (Bergman, 1990). Whereas VFA are absorbed and metabolized by the animal, $\mathrm{CH}_{4}$ escapes the rumen into the atmosphere primarily via eructation (Immig, 1996). Enteric $\mathrm{CH}_{4}$ released to the atmosphere is a major contributor to anthropogenic greenhouse gas emissions, and cattle, including dairy cows, account for $77 \%$ of the global enteric $\mathrm{CH}_{4}$ emissions (Gerber et al., 2013). Besides the environmental impact, enteric $\mathrm{CH}_{4}$ energy represents from 2 to $12 \%$ of dietary gross energy intake (Johnson and Johnson, 1995), thus decreasing the efficiency of feed energy use in ruminants. 
Technologies to reduce enteric $\mathrm{CH}_{4}$ emission in ruminants include nutritional management, use of feed additives, and genetic selection (Hristov et al., 2013). A recently discovered substance under investigation, 3-nitrooxypropanol (3-NOP; Duval and Kindermann, 2012), has been shown to inhibit methanogenesis through targeting methyl-coenzyme $\mathrm{M}$ reductase in the last step of $\mathrm{CH}_{4}$ formation by rumen archaea (Duin et al., 2016). Several studies have investigated the effects of 3-NOP on $\mathrm{CH}_{4}$ emission in dairy cattle (Hristov et al., 2015a; Melgar et al., 2018b, 2019; Van Wesemael et al., 2019). Although 3-NOP consistently decreased enteric $\mathrm{CH}_{4}$ emission, inclusion rate, application technique, diet composition, and timing of application appear to affect the extent of $\mathrm{CH}_{4}$ reduction. Reportedly, daily $\mathrm{CH}_{4}$ emission in dairy cows have been decreased from 7\% (Reynolds et al., 2014), when 3-NOP was infused directly into the rumen, to $60 \%$ (Haisan et al., 2014), when 3-NOP was mixed into the TMR. A recent study reported a $28 \%$ decrease in $\mathrm{CH}_{4}$ production in dairy cows when 3-NOP was mixed daily with the TMR and a $23 \%$ decrease when it was incorporated into a concentrate pellet (Van Wesemael et al., 2019).

The above studies were conducted with cows in mid- to late lactation. However, cows in early lactation, when experiencing negative energy balance, are likely to benefit from enteric $\mathrm{CH}_{4}$ inhibition and use feed energy more efficiently. The transition and early lactation period, when cows need to adapt to metabolic changes related to parturition, lactation, and reproductive function, are the most critical periods of the lactation cycle (Bell, 1995; Beever, 2006). Negative energy balance after calving is associated with loss of BCS, metabolic disorders, and delayed reproductive cycle (Butler and Smith, 1989; Nebel and McGilliard, 1993). Decreasing feed energy loss as enteric $\mathrm{CH}_{4}$ during early lactation is likely to trigger a positive response in productive or reproductive performance, if DMI is unaffected. Therefore, we hypothesized that the reduction in feed energy loss (as enteric $\mathrm{CH}_{4}$ energy) as a result of inhibiting enteric $\mathrm{CH}_{4}$ production would have a positive effect on lactational performance, reducing BW loss and maintaining resumption of ovarian cyclicity in early-lactation dairy cows. The objective of this study was to investigate the effect of $3-\mathrm{NOP}$ on enteric $\mathrm{CH}_{4}$ emission, rumen fermentation, lactational performance, sensory properties of milk, and the resumption of ovarian cyclicity in early-lactation Holstein cows.

\section{MATERIALS AND METHODS}

Animals involved in this experiment were cared for according to the guidelines of The Pennsylvania State University Institutional Animal Care and Use Commit- tee. The committee reviewed and approved the experiment and all procedures involving animals.

\section{Animals and Experimental Design}

The study was a 15-wk randomized complete block design and was conducted in 2 phases at The Pennsylvania State University's Dairy Teaching and Research Center (University Park) tiestall barn. Phase 1 was conducted from January to June, and phase 2 from mid-June to December 2016. The experiment had to be conducted in 2 phases due to limited tiestall space for the number of cows enrolled in the study. A total of 56 multi- and primiparous cows ( $\mathrm{n}=44$ and 12 , respectively), including 8 rumen cannulated $(10.2 \mathrm{~cm}$ internal diameter cannulas; Bar Diamond Inc., Parma, ID), were used in the experiment. Phase 1 involved 30 cows, and phase 2 involved 26 cows. Cows were blocked in 28 blocks of 2. First blocking criteria were parity and calving date. Furthermore, multiparous cows were blocked based on lactation number and previous first 100-d milk production. Primiparous cows were blocked based on their PTA milk and then BW and BCS. Cows entered the study within $3 \mathrm{~d}$ after calving and remained on the study for $105 \mathrm{~d}$. The maximum actual calving interval between cows within a block assigned to a treatment was $1 \mathrm{wk}$. Cows within block were randomly assigned to 1 of 2 experimental treatments: (1) CON (control, no 3-NOP) or (2) 3-NOP applied at $60 \mathrm{mg} /$ $\mathrm{kg}$ of feed DM. The $60 \mathrm{mg} / \mathrm{kg}$ of feed DM dose was selected based on previous experiments at The Pennsylvania State University (Hristov et al., 2015b; Lopes et al., 2016). The ration was fed as TMR, and 3-NOP was incorporated into the TMR through a premix containing (\%, DM basis) $68 \%$ ground corn grain, $6 \%$ soybean oil, $16 \%$ dry molasses, and $10 \%$ of an active or placebo supplement (DSM Nutritional Products, Basel, Switzerland). The active supplement contained $11.1 \%$ 3 -NOP on a carrier of $\mathrm{SiO}_{2}$ and propylene glycol; the placebo supplement contained the carrier $\mathrm{SiO}_{2}$ and propylene glycol only. The premixes were prepared twice a week, kept at $4^{\circ} \mathrm{C}$ in sealed containers with no headspace, and mixed daily with the TMR before feeding to deliver the final 3-NOP target concentration of $60 \mathrm{mg} /$ $\mathrm{kg}$ of feed DM as indicated above.

Cows were housed in a tiestall barn at the Dairy Research and Teaching Center of The Pennsylvania State University, fed ad libitum, and had free access to drinking water. Initially, cows were fed a fresh diet and after 3 wks in lactation were switched to a lactation diet (Table 1), targeting $15 \%$ and $10 \%$ refusals, respectively. Feed was delivered once daily at approximately $0800 \mathrm{~h}$ and pushed up to the cows 4 to 6 times daily. The basal fresh and lactation TMR were prepared us- 
ing a stationary mixer (Electra-Mix, model 1062; I. H Rissler, Mohnton, PA), and separate mixers (Rissler Mobile TMR Mixer Model 1050; I. H. Rissler) were used to mix the CON and 3-NOP TMR. The composition of the fresh and lactation diets was the same in both phases of the experiment (Table 1). Diets were formulated to meet or exceed the $\mathrm{NE}_{\mathrm{L}}$ and $\mathrm{MP}$ requirements of a fresh cow $[\mathrm{BW}=588 \mathrm{~kg}$, milk yield $(\mathbf{M Y})=$ $32 \mathrm{~kg} / \mathrm{d}$, milk fat $=3.50 \%$, milk protein $=3.00 \%$, and $\mathrm{DMI}=19 \mathrm{~kg}$ ] and a lactating cow $(\mathrm{BW}=595 \mathrm{~kg}, \mathrm{MY}$ $=43 \mathrm{~kg} / \mathrm{d}$, milk fat $=3.50 \%$, milk protein $=3.00 \%$, and DMI $=25 \mathrm{~kg}$ ) according to NRC (2001). Cows were milked twice daily at 0600 and $1800 \mathrm{~h}$. Milk from cows fed 3-NOP was discarded for the duration of the study and an additional 7-d withdrawal period.

\section{Sampling and Measurements}

Diet and Feed Ingredients. The amount of feed offered and refused was weighed individually and recorded for each cow at the time of feeding to measure daily as-fed intake during the entire experiment. Dry matter content of the TMR and refusals was determined weekly and used to calculate DMI from the as-fed TMR intake. Samples of the forages and concentrate feeds were collected once weekly, and samples of the TMR and refusals were collected twice weekly and stored at $-20^{\circ} \mathrm{C}$. Composite TMR samples were processed for particle size analysis using the Penn State Particle Separator with 19-, 8-, and 4-mm sieves, according to Heinrichs and Kononoff (2002). Feed samples were later dried for $72 \mathrm{~h}$ at $55^{\circ} \mathrm{C}$ in a forced-air oven and ground in a Wiley Mill (Thomas Scientific; Swedesboro, NJ) through a 1-mm sieve for further analysis. Forages and concentrate feeds were composited (equal DM weight basis) per phase and submitted to Cumberland Valley Analytical Services (CVAS, Waynesboro, PA) for wet chemistry analyses of CP (method 990.03; AOAC International, 2000), amylase-treated NDF (Van Soest et al., 1991), ether extract (method 2003.05; AOAC International, 2006), ADF (method 973.18; AOAC International, 2000), ash (method 942.05; AOAC International, 2000), minerals (method 985.01; AOAC International, 2000), estimated NFC (NRC, 2001), and estimated $\mathrm{NE}_{\mathrm{L}}$ (CVAS, 2018). Starch was analyzed as described in Hall (2009). The chemical composition of the diets (CP, NDF, ADF, starch, ash, $\mathrm{Ca}$, and $\mathrm{P}$ ) was calculated by using the analyzed chemical composition of the individual feed ingredients and their inclusion rate in the TMR (Table 1). The RDP, RUP, $\mathrm{NE}_{\mathrm{L}}$ and $\mathrm{NE}_{\mathrm{L}}$ balance, and NFC were estimated based on NRC (2001), using averaged DMI, MY, milk composition, and BW of the cows throughout the experiment.
Table 1. Ingredients and chemical compositions of the basal fresh and lactation TMR diets fed to early-lactation dairy cows in the experiment

\begin{tabular}{|c|c|c|}
\hline \multirow[b]{2}{*}{ Item } & \multicolumn{2}{|c|}{$\operatorname{Diet}^{1}$} \\
\hline & Fresh & Lactation \\
\hline \multicolumn{3}{|l|}{ Feed ingredient, $\%$ of diet DM } \\
\hline Corn silage $^{2}$ & 34.0 & 38.2 \\
\hline Alfalfa haylage $^{3}$ & 15.3 & 14.4 \\
\hline Grass hay & 5.1 & 5.0 \\
\hline Cottonseed, whole & 2.7 & 3.2 \\
\hline Corn grain, ground & 10.3 & 10.0 \\
\hline Candy by-product meal & 5.0 & - \\
\hline Soybean seeds, whole heated ${ }^{4}$ & 6.0 & 6.7 \\
\hline Canola meal mechanically extracted ${ }^{5}$ & 8.0 & 10.0 \\
\hline SoyPLUS ${ }^{6}$ & 5.0 & 5.0 \\
\hline Molasses $^{7}$ & 5.5 & 5.0 \\
\hline Optigen ${ }^{8}$ & 0.5 & - \\
\hline Vitamin and mineral premix ${ }^{9}$ & 2.6 & 2.5 \\
\hline \multicolumn{3}{|l|}{$\begin{array}{l}\text { Composition, }{ }^{10} \% \text { of DM } \\
\text { (or as indicated) }\end{array}$} \\
\hline $\mathrm{CP}^{10}$ & 17.8 & 17.0 \\
\hline $\mathrm{RDP}^{11}$ & 11.8 & 10.5 \\
\hline RUP $^{11}$ & 6.0 & 6.5 \\
\hline $\mathrm{NDF}^{10}$ & 31.4 & 31.5 \\
\hline $\mathrm{ADF}^{10}$ & 20.9 & 21.1 \\
\hline Ether extract & 5.4 & 5.2 \\
\hline $\mathrm{NE}_{\mathrm{L}}{ }^{10} \mathrm{Mcal} / \mathrm{kg}$ & 1.66 & 1.59 \\
\hline Average $\mathrm{NE}_{\mathrm{L}}$ balance, ${ }^{12} \mathrm{Mcal} / \mathrm{d}$ & 1.70 & 0.8 \\
\hline Average MP balance, ${ }^{12} \mathrm{~g} / \mathrm{d}$ & 55.0 & 9.0 \\
\hline $\mathrm{NFC}^{11}$ & 41.1 & 42.2 \\
\hline $\mathrm{Ca}^{10}$ & 0.84 & 0.82 \\
\hline $\mathrm{P}^{10}$ & 0.37 & 0.37 \\
\hline \multicolumn{3}{|l|}{ Ration particle size distribution, ${ }^{13}$} \\
\hline$>19.0 \mathrm{~mm}$ & 5 & 6 \\
\hline $19.0-8.0 \mathrm{~mm}$ & 37 & 39 \\
\hline $8.0-1.18 \mathrm{~mm}$ & 40 & 37 \\
\hline$<1.18 \mathrm{~mm}$ & 18 & 18 \\
\hline
\end{tabular}

${ }^{1}$ Average diets for phases 1 and 2 . Fresh diet fed from wk 1 to 3 of the experimental period; lactation diet fed from wk 4 to 15 .

${ }^{2}$ Phase 1 corn silage was 35.0\% DM and contained (DM basis) $6.9 \% \mathrm{CP}, 36.3 \%$ NDF, and $41.7 \%$ starch. Phase 2 corn silage was $36.7 \%$ DM and contained (DM basis) $7.1 \% \mathrm{CP}, 37.5 \% \mathrm{NDF}$, and $41.4 \%$ starch.

${ }^{3}$ Phase 1 haylage was $34.7 \%$ DM and contained (DM basis) $20.8 \% \mathrm{CP}$ and $47.5 \%$ NDF. Phase 2 haylage was $35.1 \%$ DM and contained (DM basis) $20.1 \% \mathrm{CP}$ and $42.1 \% \mathrm{NDF}$.

${ }^{4}$ Soybean seeds contained (DM basis) $37.4 \% \mathrm{CP}$ (Phase 1) and $41.2 \% \mathrm{CP}$ (Phase 2).

${ }^{5}$ Canola meal contained (DM basis) $42.4 \%$ CP (Phase 1) and 40.8\% CP (Phase 2).

${ }^{6}$ SoyPLUS (West Central Cooperative, Ralston, IA) contained (DM basis) $46.6 \%$ $\mathrm{CP}$.

${ }^{7}$ Molasses (Westway Feed Products, Tomball, TX) contained (DM basis) 3.9\% $\mathrm{CP}$ and $66 \%$ total sugar.

${ }^{8}$ Optigen is a slow-release urea (Alltech Inc., Nicholasville, KY).

${ }^{9}$ Premix (Cargill Animal Nutrition, Cargill Inc., Roaring Spring, PA) contained (\%, as-is basis) trace mineral mix, $0.86 ; \mathrm{MgO}(56 \% \mathrm{Mg}), 8.0 ; \mathrm{NaCl}, 6.4$; vitamin ADE premix (Cargill Animal Nutrition, Cargill Inc.), 0.48; limestone, 37.2; selenium premix (Cargill Animal Nutrition, Cargill Inc.), 0.07; and dry corn distillers grains with solubles, 46.7. Ca, $14.1 \%$; P, $0.39 \%$; Mg, $4.59 \%$; K, $0.44 \%$; $\mathrm{S}, 0.39 \%$; Se, $6.91 \mathrm{mg} / \mathrm{kg} ; \mathrm{Cu}, 362 \mathrm{mg} / \mathrm{kg} ; \mathrm{Zn}, 1,085 \mathrm{mg} / \mathrm{kg} ; \mathrm{Fe}, 186 \mathrm{mg} / \mathrm{kg}$; vitamin A, 276,717 IU/kg; vitamin D, 75,000 IU $/ \mathrm{kg}$; and vitamin E, 1,983 IU $/ \mathrm{kg}$.

${ }^{10}$ Values calculated using the chemical analysis (performed by Cumberland Valley Analytical Services Inc., Waynesboro, PA) of the feed ingredients and their inclusion in the diets.

${ }^{11}$ Estimated based on NRC (2001).

${ }^{12}$ Estimated based on NRC (2001) using actual DMI, milk yield, milk composition, and BW of the cows throughout the trial (fresh and lactation diets, respectively).

${ }^{13}$ Reported on an as-fed basis using the Penn State Particle Separator with 19-, 8-, and 4-mm sieves, based on Heinrichs and Kononoff (2002). 
Enteric Gas Emissions. Enteric gas emissions $\left(\mathrm{CH}_{4}, \mathrm{CO}_{2}\right.$, and $\left.\mathrm{H}_{2}\right)$ were measured individually for each cow during wk 2, 6, 9, and 15 using the GreenFeed system (C-Lock Inc., Rapid City, SD). Gas sampling procedures followed those recommended by Hristov et al. (2015a,b). Briefly, during each measurement week, gas emission data were collected over $3 \mathrm{~d}$ as follows: starting at 0900, 1500, and $2100 \mathrm{~h}$ (d 1), 0300, 1200, and $1700 \mathrm{~h}(\mathrm{~d} 2)$, and 0000 and $0500 \mathrm{~h}(\mathrm{~d} 3)$ to obtain a representative sample of a 24 -h feeding cycle. Individual breath gas sample were collected for $5 \mathrm{~min}$, followed by 2-min background air sample collection. Each GreenFeed unit was calibrated following the manufacturer's recommendations. A pelletized bait feed was offered at each sampling event, for a total of $4,000 \mathrm{~g} /$ cow over $3 \mathrm{~d}$, which was included in the DMI during the gas sampling week. GreenFeed is equipped with a head position sensor, and gas emission data are rejected when the cow's head position criteria are not met. A cannula extension was used when measuring gas from the cannulated cows, as described in Lopes et al. (2016). Enteric $\mathrm{CH}_{4}$ emission yield ( $\mathrm{g} / \mathrm{kg}$ DMI) and intensity $(\mathrm{g} / \mathrm{kg}$ MY or $\mathrm{g} / \mathrm{kg}$ ECM) were also calculated.

Rumen Fermentation. Whole-rumen digesta and rumen fluid samples were collected from the 8 rumencannulated cows at 2,6 , and $10 \mathrm{~h}$ after feeding in 1 day during wk 4, 8, and 12, as described in Hristov et al. (2011). Briefly, whole-rumen contents samples collected from 4 locations in the rumen were filtered through 2 layers of cheesecloth. The filtered rumen fluid was analyzed immediately for $\mathrm{pH}(59000-60 \mathrm{pH}$ Tester, Cole-Parmer Instrument Company, Vernon Hills, IL), and aliquots processed for further analyses. Samples were analyzed for concentration of individual VFA (Yang and Varga, 1989), ammonia (Chaney and Marbach, 1962), and total protozoal count (Hristov et al., 2011). An aliquot of the rumen fluid was filtered through a nylon fabric (PECAP 07-59/33; SEFAR, Heiden, Switzerland), transferred into $20-\mathrm{mL}$ scintillation vials (Fisher Scientific, Pittsburg, PA), and stored at $4^{\circ} \mathrm{C}$ until analyzed for dissolved $\mathrm{H}_{2}\left(\mathbf{d H}_{2}\right.$; Vaportech Services, Valencia, PA) according to Chapelle et al. (1997). Concentration of formic acid in ruminal fluid was analyzed using GC (packed column in stainless steel tubing, length $1.83 \mathrm{~m}, 3.175 \mathrm{~mm}$ outer diameter, 2 mm inner diameter, Chromosorb 101 packing, mesh size 80/100, preconditioned; Agilent G3591-80021, Agilent Technologies, Santa Clara, CA; using 2-ethylbutyric acid as an internal standard), and samples for analysis of ethanol concentration were submitted to CVAS.

Hydrogen balance (i.e., recovery) was estimated based on the stoichiometry equations of Marty and Demeyer (1973). Production of acetate, propionate, and butyr- ate was estimated from their concentrations using the regression equations proposed by Sutton et al. (2003). Production of valerate was assumed to be proportional to that of propionate and was estimated based on the valerate:propionate concentrations ratio. Hydrogen in microbial cells was estimated based on the equation of Marty and Demeyer (1973). Hydrogen in the $\mathrm{dH}_{2}$ ruminal pool and in minor $\mathrm{H}_{2}$ sinks, such as formic acid and ethanol, was estimated based on concentrations of $\mathrm{dH}_{2}$, formate, and ethanol in ruminal contents and assuming a rumen volume of $120 \mathrm{~L}$ (based on rumen evacuation data by Hristov and Broderick, 1996 and Hristov, 2007). Average $\mathrm{H}_{2}$ recovery (\%) for $\mathrm{CON}$ and 3-NOP was calculated as follows: $\left[\mathrm{H}_{2}\right.$ recovered in end products, mol (propionate + butyrate + valerate $+\mathrm{CH}_{4}+$ $\mathrm{H}_{2}$ gas $+\mathrm{dH}_{2}+$ microbial cells + formate + ethanol $)$ $\div \mathrm{H}_{2}$ produced, mol (acetate + propionate + butyrate + valerate) $] \times 100$. Rates of mol of $\mathrm{VFA} / \mathrm{kg}$ of DMI and moles of VFA $/ \mathrm{kg}$ of digestible OM were calculated based on estimated total daily VFA production (Sutton et al., 2003), DMI during gas emission sampling, and digestibility of OM.

Milk Production and Composition. Milk production of the cows was recorded at each milking. Milk samples were collected from 2 consecutive milkings (p.m. and a.m.) during study wk 1, 2, 3, 6, 9, 12, and 14. One aliquot of each sample was placed in tubes with a preservative (2-bromo-2-nitropropane-1, 3-diol) and submitted to Dairy One Cooperative Inc. (Ithaca, NY) for analysis of milk fat, true protein, lactose, SCC, and MUN using Milkoscan models 6000, FT+ or 7 and Fossomatic models 5000 of FC (Foss Electric A/S, Hillerød, Denmark). Milk composition data were weighted for the corresponding MY during p.m. and a.m. milkings. Another milk sample was collected during experimental wk $2,6,9$, and 12 , placed in tubes without preservative, and stored at $-20^{\circ} \mathrm{C}$ until analyzed for milk fatty acid (FA) composition as described in Rico and Harvatine (2013).

Body Weight, Body Weight Change, and Body Condition Score. Cow BW was recorded twice daily upon exiting the milking parlor using an AfiFarm 3.04E scale system (SAE Afikim, Rehovot, Israel). Cows were evaluated for BCS according to a 5-point scale (Wildman et al., 1982) by the same evaluator weekly up to experimental wk 3 and then every 2 wk throughout the remainder of the study.

Apparent Total-Tract Digestibility and Nitrogen Utilization. Spot urine and fecal samples were collected once from each cow during experimental wk 11 to estimate apparent digestibility of dietary nutrients and N utilization. Samples of urine (approximately $300 \mathrm{~mL} /$ sample) and feces (approximately $400 \mathrm{~g} /$ 
sample) were collected over $3 \mathrm{~d}$ as follows: starting at 1000, 1600, and $2200 \mathrm{~h}$ (d 1), 0400, 1300, $1900 \mathrm{~h} \mathrm{(d} \mathrm{2),}$ and 0100 and $0800 \mathrm{~h}(\mathrm{~d} 3)$ to obtain a representative sample of a 24-h feeding cycle. A full description of the urine and fecal sample processing and analyses can be found in Lee et al. (2012) and Oh et al. (2013). Briefly, raw urine from each sampling was acidified, diluted, composited per cow on an equal volume basis, stored frozen at $-20^{\circ} \mathrm{C}$, and later analyzed for total $\mathrm{N}$, urinary urea $\mathrm{N}$, creatinine, and the purine derivatives allantoin and uric acid. Total $\mathrm{N}$ was analyzed in freeze-dried urine samples of approximately $60 \mu \mathrm{L}$ of $1: 10$ diluted and acidified urine, using a Costech ECS $4010 \mathrm{C} / \mathrm{N} / \mathrm{S}$ elemental analyzer (Costech Analytical Technologies Inc., Valencia, CA). Stanbio Laboratory (Boerne, TX) kits were used to analyze urinary urea N (Urea Nitrogen Kit 580), creatinine (Creatinine Kit 420), and uric acid (Uric Acid Kit 1045). Allantoin was analyzed following the procedure described by Chen et al. (1992). Daily volume of excreted urine was estimated based on urinary creatinine concentration, assuming a creatinine excretion rate of $29 \mathrm{mg} / \mathrm{kg}$ of $\mathrm{BW}$ based on total urine collection data from Hristov et al. (2011). Excretions of daily total $\mathrm{N}$, urinary urea, and purine derivatives were calculated using the estimated urine output. Fecal samples were oven-dried at $65^{\circ} \mathrm{C}$, ground through a 1-mm screen in a Wiley Mill (Thomas Scientific), composited per cow, and analyzed for $\mathrm{OM}, \mathrm{CP}, \mathrm{NDF}$, $\mathrm{ADF}$, and starch. Analysis of $\mathrm{OM}$ was conducted by ashing the TMR samples for $4 \mathrm{~h}$ at $600^{\circ} \mathrm{C}$. A 0.5 -g aliquot of pulverized (Mixer Mill MM 200, Retsch $\mathrm{GmbH}$, Haan, Germany) fecal sample was used for CP analysis $(\mathrm{N} \times 6.25)$ using a Costech ECS $4010 \mathrm{C} / \mathrm{N} / \mathrm{S}$ elemental analyzer. The NDF and ADF were analyzed with an Ankom 200 fiber analyzer (Ankom Technology Corp., Macedon, NY) based on the procedures of Van Soest et al. (1991), using $\alpha$-amylase and sodium sulfite in the NDF analysis. Starch analysis of fecal DM for apparent total-tract digestibility was performed based on the method including acetate buffer described by Hall (2009). Briefly, starch was gelatinized with 50\% $\mathrm{NaOH}$, incubated for $16 \mathrm{~h}$ at $55^{\circ} \mathrm{C}$ with acetate buffer and amylase, centrifuged, plated on a 96-well plate, and then reacted with a glucose-oxidase-peroxidase enzyme solution (P7119; Sigma-Aldrich, Saint Louis, MO) for 45 min before being read at 450-nm filter (Victor 1420 multilabel Counter, Perkin Elmer, Waltham, MA) with the Wallac 1420 manager software version 3.00 (Perkin Elmer and Analytical Sciences, Wallac Oy, Turku, Finland). Apparent total-tract digestibility of nutrients was estimated using indigestible NDF as an intrinsic digestibility marker (Schneider and Flatt, 1975). Fecal and TMR samples were analyzed for indigestible NDF after a 12-d ruminal incubation in situ according to Huhtanen et al. (1994), with the exception that 25- $\mu \mathrm{m}$ pore size Ankom filter bags (F57; Ankom Technology) were used for the rumen incubation.

Blood Chemistry and Hormones. Blood samples were collected from the coccygeal vein or artery in one day, $3 \mathrm{~h}$ after feeding, during experimental wk 1, 2, 3, 4, 5, 6, 7, and 15. Whole blood (approximately $10 \mathrm{~mL}$ ) was collected into evacuated tubes containing EDTA (BD Biosciences, Franklin Lakes, NJ), refrigerated at $4^{\circ} \mathrm{C}$, and analyzed on the same day for blood cell counts using an automated hematology analyzer (HemaVet, Drew Scientific, Oxford, CT). A separate set of blood samples (approximately $10 \mathrm{~mL}$ ) were collected into evacuated tubes containing EDTA (BD Biosciences) for free AA analysis of plasma. Plasma was obtained via centrifugation at $1,500 \times g$ at $4^{\circ} \mathrm{C}$ for $10 \mathrm{~min}$ and stored at $-20^{\circ} \mathrm{C}$ until analysis. Samples were composited (wk 1,2 , and 3 ; wks 5,6 , and 7 ; and wk 15 ; i.e., 3 samples per cow were analyzed) per cow on an equal volume basis and sent to the University of Missouri-Columbia's Agricultural Experiment Station Chemical Laboratory for free AA analysis following the procedures of Deyl et al. (1986) and Fekkes (1996). A third set of blood samples (approximately $10 \mathrm{~mL}$ ) was collected into evacuated tubes containing silica clot activator (SST Tube; BD Biosciences) and kept at room temperature for $30 \mathrm{~min}$, and blood serum was separated after clotting through centrifugation at $3,000 \times g$ at room temperature for 15 min and stored at $-80^{\circ} \mathrm{C}$ until analysis. Serum samples from wk 1, 2, 4, 6, and 15 were analyzed for glucose (Stanbio Glucose LiquiColor, Kit 1070, Stanbio Laboratory Inc.) and blood urea N (Stanbio Urea Nitrogen Kit 0580, Stanbio Laboratory Inc.). Serum samples from the first 4 experimental weeks were also analyzed for nonesterified fatty acid (NEFA; HR Series NEFA-HR, Wako Diagnostics, Richmond, VA) and BHB (Autokit 3-HB Microliter Procedure; Wako Diagnostics). Serum samples from wk 1,2, and 3 and from wk 5, 6, and 7 were composited per cow on an equal volume basis and analyzed for leptin (Bovine Leptin ELISA Kit, Sandwich ELISA - LS-F31819, LifeSpan BioSciences Inc., Seattle WA), insulin (Bovine Insulin ELISA Kit, RayBiotech, Norcross, GA), and IGF-1 (Bovine IGF-1 ELISA Kit, RayBiotech).

Resumption of Ovarian Cyclicity. Resumption of ovarian activity was assessed by assaying milk for progesterone concentration. Samples were collected at the morning milkings on Monday, Wednesday, and Friday of each week. Collection commenced on d 14 after calving and continued until d 50. Samples were centrifuged at $2,511 \times g$ for $15 \mathrm{~min}$ at $4^{\circ} \mathrm{C}$. The fat cake was removed, and the defatted milk was stored at 
$-20^{\circ} \mathrm{C}$ until analysis. Samples were assayed via ELISA based on Munro and Stabenfeldt (1984) and validated for skim milk through the method described by Fetter (2017), using a VICTOR 1420 Multilabel Counter fitted with a 450-nm filter (Perkin Elmer) and the Wallac 1420 Manager software. Milk progesterone concentrations were plotted using GraphPad (version Prism 5, GraphPad Software Inc., La Jolla, CA) and analyzed for evidence of first corpus luteum (CL), length of first luteal phase, interval of first to second luteal phase, and evidence of second CL. To determine evidence of a CL, skim milk progesterone concentration had to be greater than or equal to $0.5 \mathrm{ng} / \mathrm{mL}$ for 2 consecutive samples. Faustini et al. (2007) indicated that plasma progesterone concentrations are 5 -fold greater than in skim milk. The cutoff concentration of $0.5 \mathrm{ng} / \mathrm{mL}$ was used, based on previous literature values citing progesterone concentrations of $2 \mathrm{ng} / \mathrm{mL}$ in plasma and whole milk when a CL was present (Etherington et al., 1991; Lamming and Darwash, 1998; Taylor et al., 2004). The length of the luteal phase was considered the time progesterone concentration remained at or above $0.5 \mathrm{ng} /$ $\mathrm{mL}$. The interval of first to second luteal phase was the time progesterone concentration remained below 0.5 $\mathrm{ng} / \mathrm{mL}$ after evidence of the first CL. All cows involved in the experiment were submitted to an ovulation synchronization program following The Pennsylvania State University's Dairy Teaching and Research Center protocols.

Milk Sensory and Cheese Acceptance Panel Evaluation. The entire MY was collected from 2 consecutive d from 6 randomly selected cows on each treatment ( $\mathrm{CON}$ and 3-NOP), composited by treatment, pasteurized, and used for milk sensory panel evaluation at the Sensory Evaluation Center in the Department of Food Science at The Pennsylvania State University. Sensory properties of milk were evaluated by an 85 -subject sensory panel. Procedures were exempted from Institutional Review Board and reviewed by professional staff in The Pennsylvania State University Office of Research Protections [exemption in 45 CFR 46.101(b) (6) for Food Taste and Acceptance Studies]. A triangle test was used to determine whether 3-NOP milk was significantly different from CON milk. Product was pasteurized, stored, and served at refrigerated temperature. Milk samples consisted of $60 \mathrm{~mL}$ of milk served in a $150-\mathrm{mL}$ clear plastic cup. Panelists were presented with 3 cups of samples (2 with CON and 1 with 3 -NOP milk, or 2 with 3 -NOP and 1 with CON milk) labeled with 3 -digit blinding codes. The presentation order was counterbalanced with the reference being presented in the left position, and panelists were instructed to identify the coded sample that was the same as the reference. Water was provided as palate cleanser. Evaluations took place in individual testing booths under white lighting, using Compusense Cloud (Compusense Inc., Guelph, ON, Canada).

Separate 3-NOP and CON milk samples were also collected on different days and processed for orange and white cheddar cheese, respectively, and an acceptance test was performed by a 111-subject sensory panel. Evaluations took place in individual testing booths under red lightning, so that color was not a determining factor, using Compusense Cloud (Compusense Inc.). Cheese samples consisted of 3 cubes of cheese served in 150-mL clear plastic cups labeled with 3-digit blinding codes. Panelists received both samples of cheese in a serial monadic design. The presentation order was balanced, so each sample was seen first by the same number of participants. Panelists were instructed to rate overall liking and comment on likes and dislikes according to a 9 -point hedonic scale $(9=$ like extremely, 8 $=$ like very much, $7=$ like moderately, $6=$ like slightly, $5=$ neither like nor dislike, $4=$ dislike slightly, $3=$ dislike moderately, $2=$ dislike very much, $1=$ dislike extremely).

\section{Statistical Analysis}

All data were analyzed using the MIXED procedure of SAS, version 9.4 (SAS Institute Inc., Cary, NC). Data were tested for normality using the UNIVARIATE procedure of SAS. Log-transformed data were analyzed when the W statistic of the Shapiro-Wilk test was less than 0.05 (i.e., SCC and protozoal counts). The statistical model included treatment, phase (phase 1 or 2), diet (fresh or lactating TMR), parity (primior multiparous), and treatment $\times$ phase, treatment $\times$ parity, and treatment $\times$ diet (where applicable) interactions. Most interactions were nonsignificant $(P>$ 0.05 ) and were removed from the final model (see table footnotes for exceptions). Block and block $\times$ treatment were random effects, and all others were fixed.

Enteric gas $\left(\mathrm{CH}_{4}, \mathrm{CO}_{2}\right.$, and $\left.\mathrm{H}_{2}\right)$ emission data $(\mathrm{g} / \mathrm{d}$ per animal) were averaged by cow and sampling week, and the average values were used in the statistical analysis. Following an examination of the data, gas emission data from the 8 rumen-cannulated cows were removed from the statistical analysis because $\mathrm{CH}_{4}$ yield for the cannulated control cows was $50 \%$ lower than the $\mathrm{CH}_{4}$ yield for intact control cows, indicating malfunctioning of the cannula extension device, leading to leakage of enteric fermentation gases to the atmosphere. This resulted in the removal of 256 data points, or $14 \%$ of all gas emission data. Averaged DMI and ECM yield during the gas sampling weeks was used to estimate 
$\mathrm{CH}_{4}$ and $\mathrm{CO}_{2}$ yield (g per $\mathrm{kg}$ of DMI) and intensity ( $\mathrm{g}$ per $\mathrm{kg}$ of ECM). Rumen fermentation data from the 8 rumen-cannulated cows were averaged by week of sampling, and the mean values were used for the statistical analysis.

Feed DMI, MY, BW, and estimated feed efficiency data were averaged by week, and the mean values were used in the statistical analysis. The mean MY and DMI during milk sampling weeks were used to calculate milk fat, true protein, lactose, and ECM yields. Energy-corrected milk $(\mathrm{kg} / \mathrm{d})$ was calculated according Sjaunja et al. (1990), and milk $\mathrm{NE}_{\mathrm{L}}$ (Mcal/d) using NRC (2001). Body weight change was calculated as the mean BW of experimental wk 14 and 15 less the mean BW of experimental wk 2 and 3. Individual BCS data (weekly for the first $3 \mathrm{wk}$ and then every $2 \mathrm{wk}$ ) were used in the statistical analysis.

Dry mater intake, MY and composition, BW, BCS, enteric gas emission, rumen fermentation, and blood chemistry and hormone data were analyzed as repeated measures using $\mathrm{AR}(1)$ covariance structure; week was the repeated term. Milk triangle test data were analyzed with Compusense Cloud (Compusense Inc.), using a binomial test to determine whether the number of participants correctly identifying the milk samples was greater than chance probability (1 of 3 correct guesses). Data from CON and 3-NOP cheddar cheese acceptance panel were analyzed with Compusense Cloud, using a 2 -sample $t$-test.
Differences were considered significant at $P \leq 0.05$, and a trend was declared at $0.05<P \leq 0.10$. Differences at $0.10<P \leq 0.15$ were considered numerical trends. Data are presented as least squares means.

\section{RESULTS}

\section{Enteric Gas Emissions}

Enteric gas emission data shown in Table 2 are for noncannulated cows only; emission data from the rumen-cannulated cows were excluded from the analysis, as specified in Materials and Methods. Dry matter intake and MY during enteric gas measurement weeks were similar between 3-NOP and CON. Compared with CON, inclusion of 3-NOP in the diet decreased $(P<$ 0.001 ) daily enteric $\mathrm{CH}_{4}$ emission by $26 \%, \mathrm{CH}_{4}$ emission yield by $21 \%$, and $\mathrm{CH}_{4}$ emission intensity (per ECM) by $25 \%$. The mitigation effect of 3 -NOP persisted throughout the duration of the experiment (Figure 1). As seen in Figure 1, enteric $\mathrm{CH}_{4}$ emission tended to increase as lactation progressed for both treatments. This observation is in line with data reported by Alstrup et al. (2015).

Carbon dioxide emission decreased $(P=0.02)$ by approximately $5 \%$ for 3 -NOP compared with CON (Table 2 ). Expressed per unit of DMI or $\mathrm{MY}, \mathrm{CO}_{2}$ emission was similar between treatments. Hydrogen emission was negligible for the CON cows throughout the experiment

Table 2. Effect of 3-nitrooxypropanol (3-NOP) on enteric gas emissions in early-lactation dairy cows

\begin{tabular}{|c|c|c|c|c|}
\hline \multirow[b]{2}{*}{ Item } & \multicolumn{2}{|c|}{ Treatment $^{1}$} & \multirow[b]{2}{*}{$\mathrm{SEM}^{2}$} & \multirow[b]{2}{*}{$P$-value ${ }^{3}$} \\
\hline & $\mathrm{CON}$ & 3 -NOP & & \\
\hline$\overline{\mathrm{DMI}},{ }^{4} \mathrm{~kg}$ & 24.4 & 23.5 & 0.63 & 0.22 \\
\hline Milk yield, ${ }^{4} \mathrm{~kg}$ & 43.8 & 43.9 & 1.59 & 0.96 \\
\hline \multicolumn{5}{|l|}{$\mathrm{CH}_{4}$} \\
\hline $\mathrm{CH}_{4}, \mathrm{~g} / \mathrm{d}$ & 362 & 269 & 8.65 & $<0.001$ \\
\hline $\mathrm{CH}_{4}$ per DMI, $\mathrm{g} / \mathrm{kg}$ & 14.9 & 11.7 & 0.48 & $<0.001$ \\
\hline $\mathrm{CH}_{4}$ per milk yield, $\mathrm{g} / \mathrm{kg}$ & 8.5 & 6.4 & 0.38 & $<0.001$ \\
\hline $\mathrm{CH}_{4}$ per $\mathrm{ECM}{ }^{5} \mathrm{~g} / \mathrm{kg}$ & 8.9 & 6.7 & 0.39 & $<0.001$ \\
\hline \multicolumn{5}{|l|}{$\mathrm{CO}_{2}$} \\
\hline $\mathrm{CO}_{2}, \mathrm{~g} / \mathrm{d}$ & 11,126 & 10,604 & 179.4 & 0.02 \\
\hline $\mathrm{CO}_{2}$ per DMI, g/kg & 461 & 465 & 11.9 & 0.77 \\
\hline $\mathrm{CO}_{2}$ per milk yield, $\mathrm{g} / \mathrm{kg}$ & 262 & 250 & 11.0 & 0.26 \\
\hline \multicolumn{5}{|l|}{$\mathrm{H}_{2}$} \\
\hline $\mathrm{H}_{2}, \mathrm{~g} / \mathrm{d}$ & 0.01 & 0.48 & 0.043 & $<0.001$ \\
\hline \multicolumn{5}{|c|}{${ }^{1}$ Treatments were control diet $(\mathrm{CON})$ and basal diet plus $60 \mathrm{mg}$ of $3-\mathrm{NOP} / \mathrm{kg}$ of feed DM (3-NOP). } \\
\hline \multicolumn{5}{|c|}{$\begin{array}{l}{ }^{2} \text { Largest SEM published in table; } \mathrm{n}=214 \text { for DMI and milk yield; } \mathrm{n}=187 \text { for gas data ( } \mathrm{n} \text { represents number } \\
\text { of observations used in the statistical analysis). Data are from } 54 \text { cows for DMI and milk yield and } 48 \text { cows for } \\
\text { gas emission, sampled on wk } 2,6,9 \text {, and } 15 \text { of the study. }\end{array}$} \\
\hline \multicolumn{5}{|c|}{$\begin{array}{l}{ }^{3} \text { Main effect of treatment. Treatment } \times \text { parity (primi- vs. multiparous) interaction, } P \geq 0.15 \text {, except } \mathrm{H}_{2}(P= \\
0.04 \text { ). Treatment } \times \text { diet (fresh vs. lactating) interaction, } P \geq 0.33 \text {. Treatment } \times \text { study phase (phase } 1 \text { or } 2) \\
\text { interaction, } P \geq 0.06 \text {, except for } \mathrm{H}_{2}(P<0.01) \text {. }\end{array}$} \\
\hline \multicolumn{5}{|c|}{${ }^{4} \mathrm{DMI}$ and milk yield during enteric gas emission measurement weeks. } \\
\hline \multicolumn{5}{|c|}{$\begin{array}{l}{ }^{5} \text { Energy-corrected milk }(\mathrm{kg} / \mathrm{d})=\mathrm{kg} \text { of milk } \times[(38.3 \times \% \text { fat } \times 10+24.2 \times \% \text { true protein } \times 10+16.54 \times \\
\% \text { lactose } \times 10+20.7) \div 3,140] ; \text { Sjaunja et al. }(1990) .\end{array}$} \\
\hline
\end{tabular}


Table 3. Effect of 3-nitrooxypropanol (3-NOP) on rumen fermentation in early-lactation dairy cows

\begin{tabular}{|c|c|c|c|c|}
\hline \multirow[b]{2}{*}{ Item } & \multicolumn{2}{|c|}{ Treatment $^{1}$} & \multirow[b]{2}{*}{$\mathrm{SEM}^{2}$} & \multirow[b]{2}{*}{$P$-value ${ }^{3}$} \\
\hline & $\mathrm{CON}$ & $3-\mathrm{NOP}$ & & \\
\hline$\overline{\mathrm{pH}}$ & 5.82 & 5.96 & 0.069 & 0.04 \\
\hline Ammonia, $\mathrm{m} M$ & 2.44 & 1.92 & 0.251 & 0.18 \\
\hline Total VFA, $\mathrm{m} M$ & 144.1 & 130.7 & 3.84 & 0.05 \\
\hline \multicolumn{5}{|l|}{ VFA, mol \% } \\
\hline Acetate & 59.1 & 54.3 & 1.08 & 0.04 \\
\hline Propionate & 25.8 & 26.7 & 1.10 & 0.51 \\
\hline Butyrate & 12.1 & 14.6 & 0.45 & 0.008 \\
\hline Isobutyrate & 0.52 & 0.65 & 0.116 & 0.42 \\
\hline Valerate & 1.63 & 2.28 & 0.169 & 0.03 \\
\hline Isovalerate & 0.88 & 1.27 & 0.149 & 0.12 \\
\hline Acetate:Propionate & 2.32 & 2.09 & 0.124 & 0.22 \\
\hline Dissolved hydrogen, $\mu \mathrm{g} / \mathrm{L}$ & 14.6 & 84.6 & 30.8 & 0.14 \\
\hline Ethanol, $\mathrm{m} M$ & 0.38 & 1.08 & 0.135 & 0.01 \\
\hline Formic acid, $\mu M$ & 37.0 & 85.4 & 4.13 & $<0.001$ \\
\hline Total protozoa, ${ }^{4} \times 10^{4} / \mathrm{mL}$ & 28.3 & 32.5 & 3.64 & 0.64 \\
\hline
\end{tabular}

but was increased $(P<0.001)$ considerably by 3 -NOP (48-fold increase). A treatment $\times$ parity interaction $(P$ $=0.04)$ and a treatment $\times$ study phase interaction $(P$ $<0.01)$ were observed for $\mathrm{H}_{2}$ emission. Examination



Figure 1. Effect of dietary supplementation with 3-nitrooxypropanol (3-NOP) on methane emission in early-lactation dairy cows over the course of the experiment. Treatments were control diet (CON) and basal diet plus $60 \mathrm{mg}$ of $3-\mathrm{NOP} / \mathrm{kg}$ of feed DM (3-NOP). Methane emission was measured using the GreenFeed system (C-Lock Inc., Rapid City, SD). Data are LSM, and error bars represent SEM; $n=24$ (number of independent data points used for each mean value). Main effect of treatment, $P<0.001$. Treatment $\times$ parity (primi- vs. multiparous), treatment $\times$ diet (fresh vs. lactating), treatment $\times$ study phase (phase 1 or 2 ), and treatment $\times$ study week interactions, $P \geq 0.19$. of the data revealed no difference $(P=0.12)$ in $\mathrm{H}_{2}$ emission between treatments for primiparous cows, although $\mathrm{H}_{2}$ emission was increased $(P<0.01)$ by 3 -NOP for multiparous cows. We found a large difference $(P<$ $0.01)$ in $\mathrm{H}_{2}$ emission between treatments during phase 1 but no difference $(P=0.13)$ during phase 2 .

\section{Rumen Fermentation}

Compared with CON, feeding 3-NOP increased $(P$ $=0.04) \mathrm{pH}$ and decreased $(P=0.05)$ concentration of total VFA, decreased $(P=0.04)$ the molar proportion of acetate, and increased the molar proportions of butyrate $(P=0.008)$ and valerate $(P=0.03$; Table $3)$. No treatment effects were observed for other VFA or for the acetate-to-propionate ratio. Concentration of ammonia in ruminal fluid was unaltered by treatment, and that of $\mathrm{dH}_{2}$ tended to be numerically increased ( $P$ $=0.14$ ) by 3 -NOP. Concentrations of minor rumen $\mathrm{H}_{2}$ sinks, such as formate and ethanol, were increased $(P$ $\leq 0.01$ ) by $3-\mathrm{NOP}$, compared with CON. Inclusion of 3 -NOP did not affect total protozoa counts in ruminal fluid.

Estimated production of the major VFA (acetate, propionate, butyrate, and valerate) in the rumen was 131.1 and $122.1 \mathrm{~mol} / \mathrm{d}(\mathrm{SEM}=5.63)$ for $\mathrm{CON}$ and $3-\mathrm{NOP}$, respectively (data not presented in tables; see Materials and Methods). Estimated acetate and propionate production were $13 \%$ and $6 \%$ lower, but butyrate and valerate production were $15 \%$ and $27 \%$, respectively, higher for 3-NOP than for CON. Total VFA production 
was 5.4 and $5.2 \mathrm{~mol} / \mathrm{kg}$ of DMI and 7.8 and $7.6 \mathrm{~mol} /$ $\mathrm{kg}$ of digestible $\mathrm{OM}$ for $\mathrm{CON}$ and 3-NOP, respectively.

\section{Feed Intake and Milk Production and Composition}

Particle size distribution data for the fresh and lactation TMR are presented in Table 1. Figure 2 shows the weekly average DMI over the entire experiment by parity (primi- vs. multiparous). Inclusion of 3-NOP decreased $(P=0.05)$ DMI compared with CON, but DMI as a percent of BW was not different between treatments (Table 4). Compared with CON, milk and ECM yield, concentrations and yields of fat, true protein, and lactose, $\mathrm{SCC}$, and milk $\mathrm{NE}_{\mathrm{L}}$ secretion were not affected by 3 -NOP. Figure 3 represents the weekly average MY over the entire experiment by parity (primi- vs. multiparous; we found no treatment $\times$ parity interaction for MY; $P=0.21)$. Compared with CON, concentration of MUN was increased $(P=0.03)$ by 3 -NOP. Feed efficiency and ECM feed efficiency were increased $(P$ $\leq 0.02$ ) by 3 -NOP compared with CON (Table 4 ). An interaction treatment $\times$ study phase was observed for milk true protein yield $(P=0.04)$. Examination of the data revealed no difference $(P=0.98)$ between treatments during phase 1 , whereas milk true protein yield was increased $(P=0.02)$ by 3 -NOP during phase 2 .

The 3-NOP diet had marked effect on milk FA profile, as the concentrations of the short-chain fatty acids 4:0 and 6:0 were increased $(P \leq 0.05)$ compared with CON (Table 5$)$. We discovered a tendency $(P=0.08)$ for increased concentration of 8:0 and decreased concentrations of 18:1 trans-10 with 3-NOP compared with CON. Concentrations of other milk FA were not affected by addition of 3-NOP to the diet. Analysis revealed a treatment $\times$ parity (primi- vs. multiparous) interaction $(P \leq 0.05)$ for cis-9 14:1, 16:0, 17:0, 18:0, trans-11 18:1, and 18:3. We also found a treatment $\times$ study phase interaction $(P \leq 0.05)$ for 4:0, 16:0, trans-6,8 18:1, trans-9 18:1, 18:3, and total trans FA. Examination of these interactions showed no obvious trends, and they were deemed of no biological significance.

Cows in the 3-NOP group had lower $(P=0.03) \mathrm{BW}$ than did the control cows (Table 4). Although the average $\mathrm{BW}$ of the cows differed between treatments, BW change, BCS, and BCS change of the cows were similar during the experiment. Body weight during wk 1 of the experiment was similar $(P=0.60)$ between treatments: 620 (SEM $=15.2 \mathrm{~kg}$; data not shown in tables). There was a treatment $\times$ parity (primi- vs. multiparous) interaction $(P=0.05)$ for BW. Analysis of the BW data by parity showed no difference between treatments within primiparous cows, whereas 3-NOP cows had lower BW $(P=0.03)$ than did control cows within the multiparous group of cows.



Figure 2. Effect of dietary supplementation with 3-nitrooxypropanol (3-NOP) on DMI of early-lactation dairy cows over the entire experiment by parity. Treatments were control diet $(\mathrm{CON})$ and basal diet plus $60 \mathrm{mg}$ of 3-NOP/ $\mathrm{kg}$ of feed DM (3-NOP). Data are LSM, and error bars represent SEM; $\mathrm{n}=3$ for primiparous; $\mathrm{n}=11$ for multiparous (n represents number of independent data points used for each mean value): $20.3 \pm 1.68$ and $20.5 \pm 1.68 \mathrm{~kg} / \mathrm{d}$ (primiparous); $24.2 \pm$ 0.75 and $23.4 \pm 0.75 \mathrm{~kg} / \mathrm{d}$ (multiparous); for CON and 3-NOP, respectively. Main effect of treatment, $P=0.05$. Treatment $\times$ week interaction, $P=0.49$. Treatment $\times$ parity (primi- vs. multiparous), $P=0.18$.

\section{Apparent Total-Tract Digestibility and Nitrogen Utilization}

Inclusion of 3-NOP in the diet tended to numerically decrease intake of DM, OM, CP, and starch $(P \leq 0.14)$, and tended to decrease intake of $\mathrm{NDF}$ and $\mathrm{ADF}(P$ $=0.10)$, as evidenced by fecal and urine sampling in experimental wk 11 (Table 6). Apparent total-tract digestibility of these dietary nutrients was not affected by treatment, except that $\mathrm{CP}$ digestibility was increased $(P=0.05)$ by 3 -NOP compared with CON. Nitrogen intake during the urine collection period tended to be numerically lower $(P=0.14)$ for 3 -NOP compared with CON (Table 7). Excretion of urinary $\mathrm{N}$, urea $\mathrm{N}$, fecal $\mathrm{N}$, and total excreta $\mathrm{N}$ tended to be decreased $(P \leq$ 0.08 ) by $3-\mathrm{NOP}$, compared with CON. Milk N secretion was unaltered by treatment. As a percent of $\mathrm{N}$ intake, cows fed 3-NOP had lower $(P=0.05)$ fecal N excretion and consequently decreased $(P=0.04)$ total excreta of $\mathrm{N}$ compared with CON cows. As percent of $\mathrm{N}$ intake, urinary $\mathrm{N}$, urinary urea $\mathrm{N}$, and milk $\mathrm{N}$ secretion were similar between treatments. A treatment $\times$ study phase interaction $(P=0.02)$ was observed for urine $\mathrm{N}$ as percent of $\mathrm{N}$ intake. Analysis of the data revealed no difference between treatments during phase $1(P=$ $0.63)$, but urine $\mathrm{N}$ as percent of $\mathrm{N}$ intake was decreased $(P=0.03)$ by 3 -NOP during phase 2 . Estimated urine output, urinary excretion of uric acid, and creatinine 
concentration in urine were not affected by treatment. Urinary excretion of allantoin and total purine derivatives were decreased $(P=0.02)$ for 3 -NOP, compared with CON.

\section{Blood Chemistry, Hormones, and Amino Acids}

Concentration of plasma urea N, glucose, NEFA, BHB, leptin, and IGF-1 were not affected by 3 -NOP (Table 8). A treatment $\times$ study phase interaction $(P$ $=0.03)$ was observed for IGF-1. Examination of the data revealed no difference between treatments during phase 1 , whereas IGF-1 tended to be increased $(P=$ 0.06 ) by 3 -NOP during phase 2 . Cows fed 3 -NOP had lower $(P=0.03)$ plasma insulin concentration than did CON cows during both fresh and lactation stages of the experiment (Figure 4). Concentration of neutrophils in blood was decreased $(P=0.04)$ by 3 -NOP, compared with CON (Table 9). We observed was a treatment $\times$ parity interaction $(P=0.03)$ for concentration of neutrophils and monocytes. Examination of the data revealed lower $(P \leq 0.03)$ neutrophil and monocyte concentrations by 3 -NOP treatment in primiparous cows, whereas no difference was found in multiparous cows. A treatment $\times$ diet interaction $(P=0.01)$ was observed for concentration of lymphocytes. Analysis of this interaction showed no overall difference between treatments during the fresh or lactating diet periods $(P \geq 0.26)$, but within $\mathrm{CON}$ cows, the concentration of lymphocytes was higher $(P<0.01)$ during the lactating diet period of the study. We also discovered treatment $\times$ study phase interactions $(P \leq 0.05)$ for the concentration of white blood cells and lymphocytes, lymphocytes as \% of total white blood cells, and mean corpuscular hemoglobin. A close examination of the data revealed no consistent differences in the response

Table 4. Effect of 3-nitrooxypropanol (3-NOP) on feed DMI, lactation performance, BW change, and BCS in early-lactation dairy cows

\begin{tabular}{|c|c|c|c|c|}
\hline \multirow[b]{2}{*}{ Item } & \multicolumn{2}{|c|}{ Treatment $^{1}$} & \multirow[b]{2}{*}{$\mathrm{SEM}^{2}$} & \multirow[b]{2}{*}{$P$-value ${ }^{3}$} \\
\hline & $\mathrm{CON}$ & 3 -NOP & & \\
\hline DMI, kg/d & 24.9 & 23.7 & 0.60 & 0.05 \\
\hline DMI, $\%$ of BW & 3.92 & 4.00 & 0.088 & 0.57 \\
\hline Milk yield, $\mathrm{kg} / \mathrm{d}$ & 43.9 & 44.1 & 1.55 & 0.91 \\
\hline Feed efficiency, ${ }^{4} \mathrm{~kg} / \mathrm{kg}$ & 1.77 & 1.88 & 0.042 & 0.01 \\
\hline Milk fat, \% & 4.03 & 4.13 & 0.085 & 0.39 \\
\hline Yield, kg/d & 1.69 & 1.74 & 0.069 & 0.54 \\
\hline $\mathrm{ECM},{ }^{5} \mathrm{~kg} / \mathrm{d}$ & 41.2 & 42.0 & 1.49 & 0.62 \\
\hline ECM feed efficiency, ${ }^{6} \mathrm{~kg} / \mathrm{kg}$ & 1.75 & 1.87 & 0.047 & 0.02 \\
\hline Milk true protein, $\%$ & 2.97 & 2.97 & 0.045 & 0.96 \\
\hline Yield, kg/d & 1.24 & 1.25 & 0.043 & 0.79 \\
\hline Milk lactose, \% & 4.81 & 4.80 & 0.029 & 0.80 \\
\hline Yield, kg/d & 2.05 & 2.06 & 0.071 & 0.88 \\
\hline MUN, mg/dL & 8.92 & 9.53 & 0.245 & 0.03 \\
\hline $\mathrm{SCC}^{7} \times 10^{3}$ cells $/ \mathrm{mL}$ & 167 & 160 & 59.7 & 0.62 \\
\hline Milk $\mathrm{NE}_{\mathrm{L}},{ }^{8} \mathrm{Mcal} / \mathrm{d}$ & 30.8 & 31.3 & 1.12 & 0.62 \\
\hline $\mathrm{BW}, \mathrm{kg}$ & 615 & 588 & 12.9 & 0.03 \\
\hline BW change, ${ }^{9} \mathrm{~g} / \mathrm{d}$ & 131 & 35.6 & 68 & 0.19 \\
\hline BCS & 3.10 & 3.20 & 0.130 & 0.51 \\
\hline BCS change $^{10}$ & -0.056 & -0.120 & 0.0540 & 0.36 \\
\hline
\end{tabular}

${ }^{1}$ Treatments were control diet (CON) and basal diet plus $60 \mathrm{mg}$ of $3-\mathrm{NOP} / \mathrm{kg}$ of feed DM (3-NOP).

${ }^{2}$ Largest SEM published in table; $\mathrm{n}=810$ for DMI, milk yield, feed efficiency, BW, and DMI as \% of BW; $\mathrm{n}=$ 486 for BCS; $\mathrm{n}=56$ for BW change; $\mathrm{n}=392$ for milk composition data ( $\mathrm{n}$ represents number of observations used in the statistical analysis). Milk composition data are from 56 cows sampled on wk 1, 2, 3, 6, 9, 12, and 14 of the study.

${ }^{3}$ Main effect of treatment. Treatment $\times$ parity (primi- vs. multiparous) interaction, $P \geq 0.07$, except BW $(P$ $=0.05$ ). Treatment $\times \operatorname{diet}$ (fresh vs. lactating) interaction, $P \geq 0.10$. Treatment $\times$ study phase (phase 1 or 2 ) interaction, $P \geq 0.09$, except for milk true protein yield $(P=0.04)$.

${ }^{4}$ Milk yield $\div$ DMI.

${ }^{5}$ Energy-corrected milk $(\mathrm{kg} / \mathrm{d})=\mathrm{kg}$ of milk $\times[(38.3 \times \%$ fat $\times 10+24.2 \times \%$ true protein $\times 10+16.54 \times$ $\%$ lactose $\times 10+20.7) \div 3,140]$; Sjaunja et al. (1990).

${ }^{6}$ ECM yield $\div$ DMI.

${ }^{7}$ Statistical analysis was performed on log-transformed data.

${ }^{8} \mathrm{Milk} \mathrm{NE}_{\mathrm{L}}(\mathrm{Mcal} / \mathrm{d})=\mathrm{kg}$ of milk $\times(0.0929 \times \%$ fat $+0.0563 \times \%$ true protein $+0.0395 \times \%$ lactose $) ; \mathrm{NRC}$ (2001).

${ }^{9} \mathrm{BW}$ change $=$ (average BW wk 14 and $15-$ average BW wk 2 and 3$) \div$ days on study.

${ }^{10} \mathrm{BCS}$ change $=\mathrm{BCS}$ on wk $15-\mathrm{BCS}$ on wk 1. 
to treatment for these parameters between phase 1 and 2. Concentration of red blood cells was unaffected by treatment, although we noted a numerical decrease $(P$ $=0.11$ ) by about $4 \%$ for 3 -NOP. Hemoglobin concentration tended to decrease $(P=0.07)$, and hematocrit ratio was decreased $(P=0.05)$ by $3-\mathrm{NOP}$, compared with CON. Concentration and volume of platelets were similar between treatments.

The sums of EAA and of NEAA were not affected by 3 -NOP, although we noted a numerical decrease $(P=$ 0.15 ) in EAA by about $5 \%$ for 3 -NOP (Table 10). Within EAA, plasma Arg concentrations were decreased $(P=$ $0.03)$, whereas Lys and Val tended to be increased $(P \leq$ 0.08 ) by 3 -NOP compared with CON. Within NEAA, Cit concentration was decreased $(P=0.004)$, Tau was increased $(P<0.001)$, while Ala and Orn tended to be increased $(P=0.07)$ by 3 -NOP compared with CON. A numerical increase with feeding 3 -NOP was observed for Cys and Hyp $(P=0.14)$. Plasma sarcosine and 1-methylhistidine concentrations were increased $(P \leq$ $0.03)$, and that of $\alpha$-amino adipic acid tended to be decreased $(P=0.06)$ for 3 -NOP versus CON. Plasma concentrations of the other AA and the dipeptide carnosine were not affected by treatment. Treatment $\times$ parity interactions $(P \leq 0.05)$ were observed for Met, Phe, Ala, Cit, Tau, and Trp, and a treatment $\times$ diet interaction was observed for phosphoserine $(P=0.04)$. Examination of these interactions showed no obvious

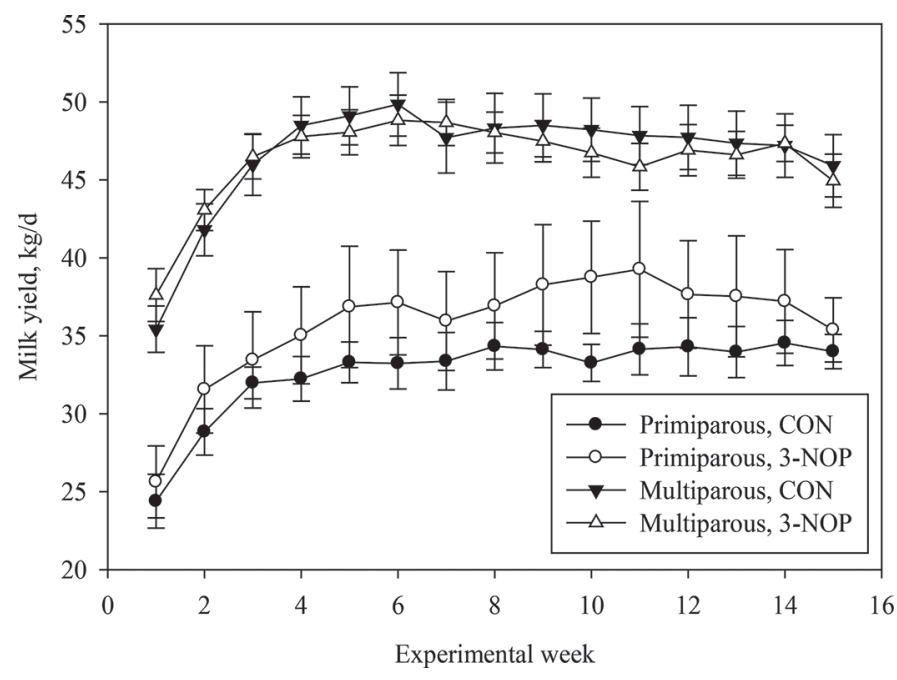

Figure 3. Effect of dietary supplementation with 3-nitrooxypropanol (3-NOP) on milk yield of early-lactation dairy cows over the entire experiment by parity. Treatments were control diet $(\mathrm{CON})$ and basal diet plus $60 \mathrm{mg}$ of 3-NOP/ $\mathrm{kg}$ of feed DM (3-NOP). Data are LSM, and error bars represent SEM; $\mathrm{n}=3$ for primiparous; $\mathrm{n}=11$ for multiparous (n represents number of independent data points used for each mean value): $30.4 \pm 2.78$ and $33.0 \pm 2.78 \mathrm{~kg} / \mathrm{d}$ (primiparous); $43.1 \pm$ 1.63 and $43.4 \pm 1.63 \mathrm{~kg} / \mathrm{d}$ (multiparous); for CON and 3-NOP, respectively. Main effect of treatment, $P=0.91$. Treatment $\times$ week interaction, $P=0.88$. Treatment $\times$ parity (primi- vs. multiparous), $P=0.21$. trends, and they were deemed of no biological significance.

\section{Resumption of Ovarian Cyclicity}

We found no effect of 3 -NOP on the resumption of ovarian cyclicity based on the evidence of presence of first CL, length of the first luteal phase, interval of first to second luteal phase, and presence of a second CL (Table 11).

\section{Milk Sensory and Cheese Acceptance Panel Evaluations}

Milk sensory and cheese acceptance panel evaluation data are not shown in tables. Analysis of the sensory results of the panel evaluations indicated that milk from cows fed 3-NOP was not different from CON milk $(P=0.23 ; 32$ out of 85 respondents correctly identified 3-NOP milk as different from CON milk). Overall liking according to the 9-point hedonic scale (mean \pm SD) for the 111 panelists was similar between CON and 3 -NOP cheeses $(P=0.38 ; 6.8 \pm 1.59$ and $6.7 \pm 1.45$, respectively).

\section{DISCUSSION}

Studies of 3-NOP in dairy cows have shown consistent decreases in enteric $\mathrm{CH}_{4}$ emission and yield, but dose, administration technique, and diet composition also appear to play important roles in the extent of $\mathrm{CH}_{4}$ emission reduction (Dijkstra et al., 2018). The $\mathrm{CH}_{4}$ mitigation effect is substantial immediately following administration but is transient during the day and depends on 3-NOP intake with the feed (Reynolds et al., 2014; Hristov and Melgar, 2019). In a recent long-term experiment, the mitigation effect of $3-\mathrm{NOP}$ in dairy cattle was found to be nonexistent before feeding and was the highest (a $45 \%$ decrease compared with the control) within $6 \mathrm{~h}$ after feeding (Hristov and Melgar, 2019). Due to its molecular structure, 3-NOP is highly soluble and rapidly metabolizable in the rumen (Duin et al., 2016). Inclusion of 3-NOP in the TMR in the current study allowed for continual consumption of 3-NOP throughout the day and decreased daily $\mathrm{CH}_{4}$ emission, emission yield, and emission intensity. The inhibitory effect of 3-NOP on methanogenesis persisted over 15 wk of treatment when applied daily in TMR, decreased overall $\mathrm{CO}_{2}$ emission, and increased emission of $\mathrm{H}_{2}$. Conversely to the current study, Hristov et al. (2015b) did not observe differences in $\mathrm{CO}_{2}$ emission between control and cows fed 3-NOP mid- to late-lactation. Emission of $\mathrm{CO}_{2}$ related to DMI was not different between treatments in the current experiment. Therefore, 
Table 5. Effect of 3-nitrooxypropanol (3-NOP) on fatty acid composition of milk fat ( $\mathrm{g} / 100 \mathrm{~g}$ of total fatty acids) in early-lactation dairy cows

\begin{tabular}{|c|c|c|c|c|}
\hline \multirow[b]{2}{*}{ Item } & \multicolumn{2}{|c|}{ Treatment $^{1}$} & \multirow[b]{2}{*}{$\mathrm{SEM}^{2}$} & \multirow[b]{2}{*}{$P$-value ${ }^{3}$} \\
\hline & $\mathrm{CON}$ & $3-\mathrm{NOP}$ & & \\
\hline $4: 0$ & 5.28 & 5.50 & 0.075 & 0.04 \\
\hline $6: 0$ & 2.37 & 2.49 & 0.056 & 0.05 \\
\hline $8: 0$ & 1.16 & 1.24 & 0.040 & 0.08 \\
\hline 10:0 & 2.33 & 2.42 & 0.102 & 0.44 \\
\hline $12: 0$ & 2.47 & 2.53 & 0.112 & 0.66 \\
\hline 14:0 & 8.39 & 8.13 & 0.254 & 0.42 \\
\hline cis-9 14:1 & 0.49 & 0.51 & 0.020 & 0.46 \\
\hline $15: 0$ & 0.81 & 0.80 & 0.031 & 0.98 \\
\hline $16: 0$ & 24.4 & 24.0 & 0.325 & 0.30 \\
\hline cis-9 16:1 & 1.15 & 1.18 & 0.061 & 0.63 \\
\hline $17: 0$ & 0.57 & 0.58 & 0.013 & 0.37 \\
\hline $18: 0$ & 14.8 & 14.9 & 0.254 & 0.63 \\
\hline trans-4 18:1 & 0.028 & 0.027 & 0.0013 & 0.46 \\
\hline trans-5 18:1 & 0.022 & 0.020 & 0.0011 & 0.31 \\
\hline trans-6,8 18:1 & 0.39 & 0.38 & 0.010 & 0.37 \\
\hline trans-9 18:1 & 0.31 & 0.30 & 0.007 & 0.60 \\
\hline trans-10 18:1 & 0.69 & 0.55 & 0.057 & 0.08 \\
\hline trans-11 18:1 & 1.48 & 1.39 & 0.079 & 0.40 \\
\hline trans-12 18:1 & 0.52 & 0.52 & 0.022 & 0.98 \\
\hline cis-9 18:1 & 21.5 & 21.4 & 0.643 & 0.88 \\
\hline cis-11 18:1 & 0.92 & 0.89 & 0.034 & 0.48 \\
\hline cis-9,cis-12 18:2 & 3.02 & 2.98 & 0.053 & 0.64 \\
\hline $18: 3$ & 0.49 & 0.48 & 0.007 & 0.54 \\
\hline $20: 0$ & 0.15 & 0.14 & 0.003 & 0.26 \\
\hline cis-9,trans-11 CLA ${ }^{4}$ & 0.48 & 0.46 & 0.016 & 0.18 \\
\hline Others & 3.13 & 3.08 & 0.084 & 0.63 \\
\hline Total trans fatty acids & 3.44 & 3.19 & 0.133 & 0.19 \\
\hline$\Sigma$ SFA & 57.5 & 57.2 & 0.62 & 0.75 \\
\hline$\Sigma$ MUFA & 27.5 & 27.1 & 0.71 & 0.66 \\
\hline$\Sigma$ PUFA & 3.99 & 3.92 & 0.059 & 0.41 \\
\hline \multicolumn{5}{|c|}{${ }^{1}$ Treatments were control diet $(\mathrm{CON})$ and basal diet plus $60 \mathrm{mg}$ of $3-\mathrm{NOP} / \mathrm{kg}$ of feed DM (3-NOP). } \\
\hline \multicolumn{5}{|c|}{$\begin{array}{l}{ }^{2} \text { Largest SEM published in table; } \mathrm{n}=112 \text { ( } \mathrm{n} \text { represents number of observations used in the statistical analysis). } \\
\text { Data are from } 56 \text { cows. } \\
{ }^{3} \text { Main effect of treatment. Treatment } \times \text { parity (primi- vs. multiparous) interaction, } P \geq 0.06 \text {, except cis- } 9 \\
14: 1,16: 0,17: 0,18: 0 \text {, trans- } 1118: 1 \text {, and } 18: 3(P \leq 0.05) \text {. Treatment } \times \text { diet (fresh vs. lactating) interaction, } P \\
\geq 0.21 \text {. Treatment } \times \text { study phase (phase } 1 \text { or } 2) \text { interaction, } P \geq 0.06 \text {, except } 4: 0,16: 0 \text {, trans-6,8 18:1, trans- } 9 \\
18: 1,18: 3 \text {, and total trans fatty acids }(P \leq 0.05) \text {. } \\
{ }^{4} \text { cis- } 12 \text {, trans-10 CLA was } \leq 0.001 \% \text {. }\end{array}$} \\
\hline
\end{tabular}

the decrease in $\mathrm{CO}_{2}$ observed in 3-NOP cows is likely a result of the numerically lower DMI in 3-NOP cows.

Inhibition of methanogenesis by $3-\mathrm{NOP}$ was accompanied by an increase in rumen $\mathrm{pH}$ and decreased total VFA concentration, and resulted in decreased molar proportion of acetate and increased butyrate and valerate. Similar effects were reported by Guyader et al. (2017) and in a meta-analysis of in vitro data by Ungerfeld (2018). Haisan et al. (2017) reported no effect of 3 -NOP on ruminal $\mathrm{pH}$ and total VFA, but molar proportion of acetate was decreased, and molar proportion of propionate was increased in dairy cows. Decreased molar proportion of acetate is commonly observed in cows fed 3-NOP (Haisan et al., 2014; Reynolds et al., 2014; Lopes et al., 2016) and can be related to $\mathrm{H}_{2}$ accumulation due to the inhibition of $\mathrm{CH}_{4}$ synthesis (van Lingen et al., 2016). Consistent with the current data,
Lopes et al. (2016) reported an increase in butyrate, valerate, and isovalerate molar proportions by $3-\mathrm{NOP}$, but, unlike the current experiment, they also observed an increased proportion of propionate with 3-NOP. Valerate is formed by condensation of acetate and propionate (Gray et al., 1952) and can be a net sink for $\mathrm{H}_{2}$ (Russell, 2002), which may explain the increased valerate among 3-NOP cows in the current experiment.

Under inhibited methanogenesis, propionate synthesis is an alternate mechanism to utilize excess $\mathrm{H}_{2}$ (McAllister and Newbold, 2008), but the relation between propionate synthesis and $\mathrm{CH}_{4}$ production in the rumen is not clear (Hart et al., 2008; Reynolds et al., 2014; Ungerfeld, 2018). Acetate, butyrate, $\mathrm{H}_{2}$, and $\mathrm{CO}_{2}$ are direct products of the activities of specific bacteria or protozoa in the rumen, whereas production of propionate and $\mathrm{CH}_{4}$ requires interaction between species 
Table 6. Effect of 3-nitrooxypropanol (3-NOP) on intake and apparent total-tract digestibility of dietary nutrients in early-lactation dairy cows

\begin{tabular}{|c|c|c|c|c|}
\hline \multirow[b]{2}{*}{ Item } & \multicolumn{2}{|c|}{ Treatment $^{1}$} & \multirow[b]{2}{*}{$\mathrm{SEM}^{2}$} & \multirow[b]{2}{*}{$P$-value ${ }^{3}$} \\
\hline & $\mathrm{CON}$ & $3-\mathrm{NOP}$ & & \\
\hline \multicolumn{5}{|c|}{ Intake, $\mathrm{kg} / \mathrm{d}$} \\
\hline $\mathrm{DM}^{4}$ & 26.5 & 25.3 & 0.70 & 0.11 \\
\hline $\mathrm{OM}$ & 24.8 & 23.7 & 0.66 & 0.11 \\
\hline $\mathrm{CP}$ & 4.17 & 3.99 & 0.115 & 0.14 \\
\hline NDF & 8.14 & 7.76 & 0.207 & 0.10 \\
\hline $\mathrm{ADF}$ & 5.81 & 5.54 & 0.144 & 0.10 \\
\hline Starch & 6.46 & 6.16 & 0.170 & 0.11 \\
\hline \multicolumn{5}{|c|}{ Apparent total-tract digestibility, \% } \\
\hline $\mathrm{DM}$ & 66.6 & 67.0 & 0.59 & 0.41 \\
\hline $\mathrm{OM}$ & 67.6 & 68.0 & 0.58 & 0.41 \\
\hline $\mathrm{CP}$ & 63.7 & 65.6 & 0.95 & 0.05 \\
\hline NDF & 41.1 & 40.9 & 0.87 & 0.83 \\
\hline $\mathrm{ADF}$ & 37.3 & 37.2 & 0.85 & 0.98 \\
\hline Starch & 97.4 & 97.5 & 0.14 & 0.58 \\
\hline
\end{tabular}

${ }^{1}$ Treatments were control diet (CON) and basal diet plus $60 \mathrm{mg}$ of $3-\mathrm{NOP} / \mathrm{kg}$ of feed DM (3-NOP).

${ }^{2}$ Largest SEM published in table; $\mathrm{n}=56$ ( $\mathrm{n}$ represents number of observations used in the statistical analysis). Data are from 56 cows.

${ }^{3}$ Main effect of treatment. Treatment $\times$ parity (primi- vs. multiparous) interaction, $P \geq 0.05$. Treatment $\times$ study phase (phase 1 or 2 ) interaction, $P \geq 0.21$.

${ }^{4} \mathrm{DM}$ intake is for the fecal collection period, wk 11.

(Wolin et al., 1997). Although propionate synthesis is lar proportion of propionate remained unchanged by the thermodynamically favored pathway under high $\mathrm{H}_{2} \quad 3$-NOP in the current experiment, suggesting a possible pressures (Ellis et al., 2008; Janssen, 2010), the mo- redirection of $\mathrm{H}_{2}$ to alternative metabolic pathways. As

Table 7. Effect of 3-nitrooxypropanol (3-NOP) on nitrogen utilization and urinary purine derivatives excretion in early-lactation dairy cows

\begin{tabular}{lcccc}
\hline & \multicolumn{2}{c}{ Treatment $^{1}$} & & \\
\cline { 2 - 2 } Item & CON & 3-NOP & SEM $^{2}$ & P-value $^{3}$ \\
\hline N intake, g/d & 667 & 638 & 18.4 & 0.14 \\
N excretion or secretion, g/d & & & & \\
Urine N & 146 & 124 & 10.0 & 0.08 \\
UUN & 96.5 & 88.6 & 5.43 & 0.004 \\
Fecal N & 242 & 219 & 8.6 & 0.05 \\
Total excreta N & 388 & 343 & 13.2 & 0.009 \\
Milk N & 199 & 197 & 7.1 & 0.80 \\
As \% of N intake & & & & \\
Urine N & 21.9 & 19.8 & 1.44 & 0.26 \\
UUN & 14.5 & 14.1 & 0.78 & 0.46 \\
Fecal N & 36.3 & 34.4 & 0.95 & 0.05 \\
Total excreta N & 58.2 & 54.1 & 1.57 & 0.04 \\
Milk N & 29.7 & 30.8 & 0.55 & 0.15 \\
Urine output, kg/d & 20.4 & 19.5 & 0.78 & 0.28 \\
Urinary PD & & & & \\
Allantoin & & & & \\
Uric acid & 643 & 587 & 30.4 & 0.02 \\
Total PD & 76.7 & 72.4 & 4.04 & 0.29 \\
Creatinine, mg/L & 720 & 660 & 33.1 & 0.02 \\
\hline
\end{tabular}

${ }^{1}$ Treatments were control diet (CON) and basal diet plus $60 \mathrm{mg}$ of $3-\mathrm{NOP} / \mathrm{kg}$ of feed DM (3-NOP).

${ }^{2}$ Largest SEM published in table; $\mathrm{n}=56$ ( $\mathrm{n}$ represents number of observations used in the statistical analysis). Data are from 56 cows sampled on wk 11 of the study.

${ }^{3}$ Main effect of treatment. Treatment $\times$ parity (primi- vs. multiparous) interaction, $P \geq 0.05$. Treatment $\times$ study phase (phase 1 or 2 ) interaction, $P \geq 0.06$, except urine $\mathrm{N}$ as $\%$ of intake $(P=0.02)$.

${ }^{4} \mathrm{UUN}=$ urinary urea nitrogen

${ }^{5} \mathrm{PD}=$ purine derivatives. 


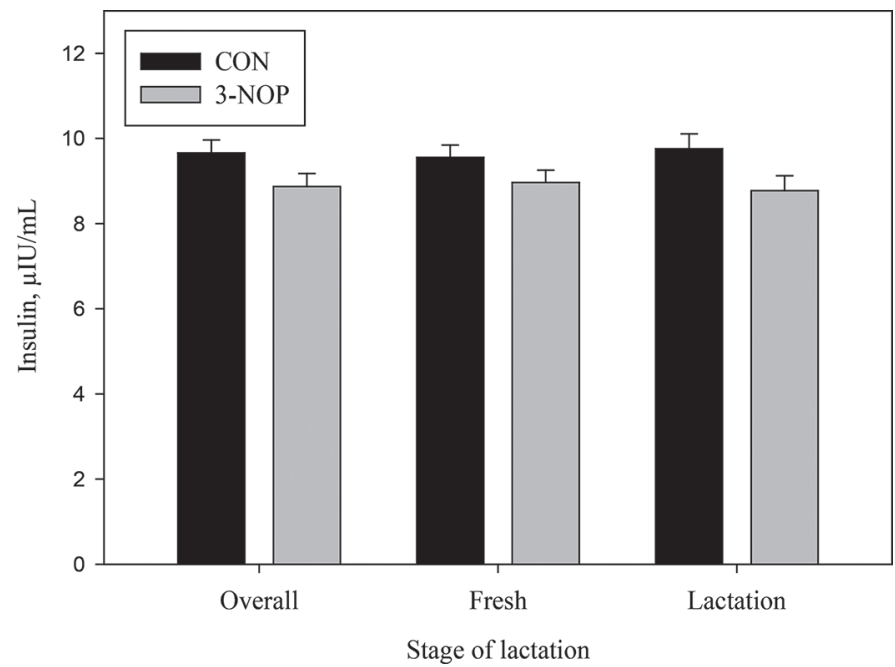

Figure 4. Effect of dietary supplementation with 3-nitrooxypropanol (3-NOP) on plasma insulin concentration $(\mu \mathrm{IU} / \mathrm{mL})$ in earlylactation dairy cows. Treatments were control diet $(\mathrm{CON})$ and basal diet plus $60 \mathrm{mg}$ of 3-NOP $/ \mathrm{kg}$ of feed DM (3-NOP). Data are LSM, and error bars represent SEM; $\mathrm{n}=56$ ( $\mathrm{n}$ represents number of independent data points used for each mean value): $9.66 \pm 0.306$ and $8.87 \pm 0.306$ $\mu \mathrm{IU} / \mathrm{mL}$ (overall); $9.55 \pm 0.292$ and $8.96 \pm 0.292 \mu \mathrm{IU} / \mathrm{mL}$ (fresh diet); and $9.76 \pm 0.349$ and $8.77 \pm 0.349 \mu \mathrm{IU} / \mathrm{mL}$ (lactation diet) for CON and 3-NOP, respectively. Main effect of treatment: overall, $P=0.03$ fresh diet, $P=0.11$; lactation diet, $P=0.02$. Treatment $\times$ parity (primi- vs. multiparous) interaction, $P=0.09$. Treatment $\times \operatorname{diet}$ (fresh vs. lactation) interaction, $P=0.15$. Treatment $\times$ study phase (phase 1 or 2 ) interaction, $P=0.19$.

suggested by Ungerfeld (2015), the significance of formate, a precursor for methanogenesis (Hungate et al., 1970) and FA synthesis, as an alternative $\mathrm{H}_{2}$ sink may increase under inhibited methanogenesis.

The increased rumen fluid $\mathrm{pH}$ observed in 3-NOP cows in the current experiment is consistent with the decrease in total VFA concentration (also reported by Reynolds et al., 2014) and perhaps with the increased proportion of butyrate. Butyrate synthesis in the rumen leads to increased $\mathrm{pH}$ due to an additional proton removal (Penner et al., 2009), whereas formation of acetate and propionate decreases $\mathrm{pH}$ (van Lingen et al., 2016). Overall rumen $\mathrm{pH}$ in both treatments was lower than values reported by Lopes et al. (2016). Analysis of the TMR particle size distribution is in agreement with the recommendations of Heinrichs and Kononoff (2002) for TMR fed to dairy cows.

Concentration of formate (along with ethanol) in ruminal fluid, although very low, was increased with addition of 3-NOP in the current experiment, but besides the tendency to decrease trans-10 18:1 FA, we did not observe any changes in milk FA as a proxy of rumen biohydrogenation (Dijkstra et al., 2011). Other studies have also observed that ruminal biohydrogenation pathways were not affected under $\mathrm{CH}_{4}$ inhibition by 3-NOP (Reynolds et al., 2014; Hristov et al., 2015b) or bromochloromethane (Abecia et al., 2012). The increase in ethanol is consistent with findings reported by Wolin et al. (1997), who suggested that accumulation of $\mathrm{H}_{2}$ in the rumen inhibits NADH oxidation, thus increasing synthesis of ethanol (also reported by Reynolds et al., 2014).

The increased $\mathrm{H}_{2}$ emission when cows were fed the 3 -NOP diet reflects the accumulation of $\mathrm{H}_{2}$ in the rumen due to inhibited methanogenesis. Consistent with previous studies performed in our laboratory (Hristov et al., 2015b; Lopes et al., 2016), the decrease in enteric $\mathrm{CH}_{4}$ emission by $3-\mathrm{NOP}$ was accompanied by an increase in $\mathrm{H}_{2}$ emissions. Similar increases in $\mathrm{H}_{2}$ emission were reported by Trei et al. (1972), Soliva et al. (2011), and van Zijderveld et al. (2011), when studying different types of $\mathrm{CH}_{4}$ inhibitors in ruminants. Hydrogen in the rumen is a fermentation intermediate (Hungate, 1967) that can be present in the liquid or gas phase

Table 8. Effect of 3-nitrooxypropanol (3-NOP) on blood metabolites and hormones in early-lactation dairy cows

\begin{tabular}{|c|c|c|c|c|}
\hline \multirow[b]{2}{*}{ Item } & \multicolumn{2}{|c|}{ Treatment $^{1}$} & \multirow[b]{2}{*}{$\mathrm{SEM}^{2}$} & \multirow[b]{2}{*}{$P$-value ${ }^{3}$} \\
\hline & $\mathrm{CON}$ & 3 -NOP & & \\
\hline Glucose, mg/dL & 51.9 & 51.1 & 1.20 & 0.57 \\
\hline Urea N, mg/dL & 11.9 & 11.2 & 0.47 & 0.36 \\
\hline $\mathrm{NEFA},{ }^{4} \mu \mathrm{Eq} / \mathrm{L}$ & 341 & 359 & 25.3 & 0.58 \\
\hline $\mathrm{BHB}, \mu M$ & 534 & 536 & 18.04 & 0.94 \\
\hline Leptin, ng/mL & 4.15 & 4.17 & 0.097 & 0.91 \\
\hline IGF-1, ng/mL & 36.2 & 37.4 & 2.33 & 0.60 \\
\hline
\end{tabular}

${ }^{1}$ Treatments were control (CON) and basal diet plus $60 \mathrm{mg}$ of $3-\mathrm{NOP} / \mathrm{kg}$ of feed DM (3-NOP).

${ }^{2}$ Largest SEM published in table; $\mathrm{n}=280$ for glucose and urea $\mathrm{N} ; \mathrm{n}=224$ for NEFA and BHB; $\mathrm{n}=112$ for leptin and IGF-1 (n represents number of observations used in the statistical analysis). Data are from 56 cows. ${ }^{3}$ Main effect of treatment. Treatment $\times$ parity (primi- vs. multiparous) interaction, $P \geq 0.17$. Treatment $\times$ $\operatorname{diet}$ (fresh vs. lactating) interaction, $P \geq 0.12$. Treatment $\times$ study phase (phase 1 or 2 ) interaction, $P \geq 0.07$, except IGF-1 $(P=0.03)$.

${ }^{4} \mathrm{NEFA}=$ nonesterified fatty acids. 
Table 9. Effect of 3-nitrooxypropanol (3-NOP) on blood cell counts in early-lactation dairy cows

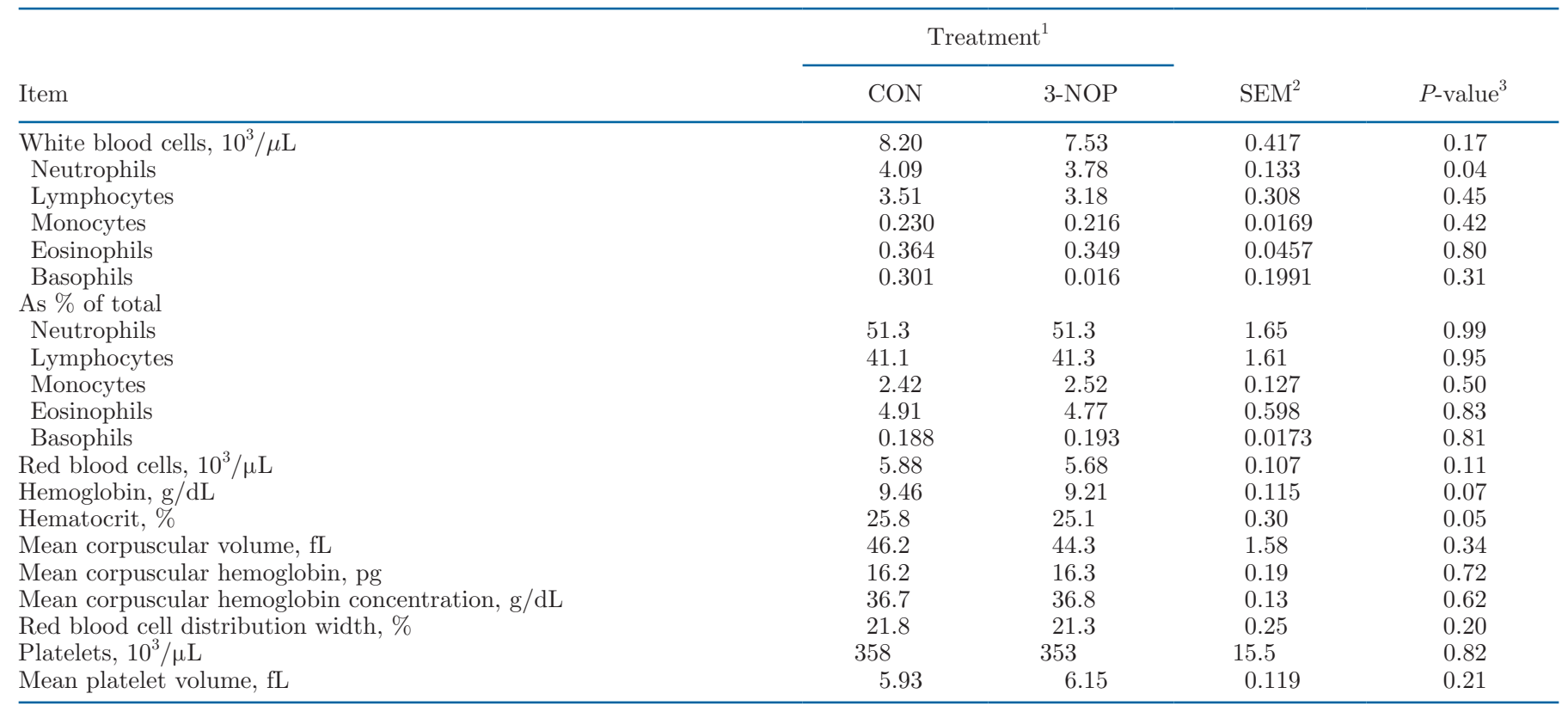

${ }^{1}$ Treatments were control (CON) and basal diet plus $60 \mathrm{mg}$ of $3-\mathrm{NOP} / \mathrm{kg}$ of feed DM (3-NOP).

${ }^{2}$ Largest SEM published in table; $\mathrm{n}=421$ ( $\mathrm{n}$ represents number of observations used in the statistical analysis). Data are from 56 cows.

${ }^{3}$ Main effect of treatment. Treatment $\times$ parity (primi- vs. multiparous) interaction, $P \geq 0.23$, except cell concentration of neutrophils and monocytes $(P=0.03)$. Treatment $\times$ diet (fresh vs. lactating) interaction, $P \geq 0.17$, except cell concentration of lymphocytes $(P=0.01)$. Treatment $\times$ study phase (phase 1 or 2 ) interaction, $P \geq 0.06$, except concentration of white blood cells and lymphocytes, lymphocytes as percent of total, mean corpuscular hemoglobin $(P \leq 0.05)$.

(Janssen, 2010) and is primarily removed via $\mathrm{CH}_{4}$ synthesis (Ellis et al., 2008). If $4 \mathrm{~mol}$ of $\mathrm{H}_{2}$ are required to yield $1 \mathrm{~mol}$ of $\mathrm{CH}_{4}$, the $93 \mathrm{~g} / \mathrm{d}$ average reduction $(362$ vs. $269 \mathrm{~g} / \mathrm{d})$ in $\mathrm{CH}_{4}$ emission with $3-\mathrm{NOP}$ in the current experiment would represent $23.2 \mathrm{~g}$ of $\mathrm{H}_{2}$ not being used for $\mathrm{CH}_{4}$ synthesis. The estimated $\mathrm{H}_{2}$ recovery was 89 and $84 \%$ for CON and 3-NOP, respectively (data not shown). Consistent with our data, Marty and Demeyer (1973) reported $95 \% \mathrm{H}_{2}$ recovery in incubations without inhibitors, whereas $\mathrm{H}_{2}$ recovery was $85 \%$ in the presence of inhibitors. Ungerfeld (2015) reported 68 to $95 \%$ metabolic $\mathrm{H}_{2}$ recovery in uninhibited continuous and batch culture in vitro systems, respectively, and below $60 \%$ recovery for $100 \%$ inhibited systems. When $\mathrm{CH}_{4}$ production was inhibited by $3-\mathrm{NOP}$, Guyader et al. (2017) reported less than $60 \% \mathrm{H}_{2}$ recovery using a rumen simulation technique, and Vyas et al. (2018) reported $54 \%$ recovery in beef cattle in vivo. In the present experiment, major VFA (propionate, butyrate, and valerate), microbial cells, and minor $\mathrm{H}_{2}$ sinks such as formate, ethanol, and $\mathrm{dH}_{2}$ in the rumen accounted for $57 \%$ of the metabolic $\mathrm{H}_{2}$ produced but not utilized for $\mathrm{CH}_{4}$ synthesis. The increase in daily $\mathrm{H}_{2}$ emission in 3 -NOP cows was a negligible fraction $(0.13 \%)$ of the $\mathrm{H}_{2}$ produced but not used for enteric $\mathrm{CH}_{4}$ synthesis. Thus, the fate of $\mathrm{H}_{2}$ under $\mathrm{CH}_{4}$ inhibition by $3-\mathrm{NOP}$ in the rumen remains an important scientific question that needs to be addressed.

No change in total protozoa counts was observed with 3 -NOP in the current experiment, which is consistent with results reported by others (Haisan et al., 2014, 2017; Romero-Perez et al., 2014, 2015). Rumen protozoa are $\mathrm{H}_{2}$ producers and increase intraruminal $\mathrm{N}$ cycling and ammonia concentration (Morrison and Mackie, 1996). Methanogens colonize protozoa to scavenge $\mathrm{H}_{2}$, and defaunation has been one of the proposed strategies to mitigate enteric $\mathrm{CH}_{4}$ production in ruminants (Morgavi et al., 2010). In the current experiment, only total protozoa count was performed, suggesting that the comparison of different protozoal species should be considered in further studies under $\mathrm{CH}_{4}$ inhibition by 3-NOP.

Supplementation with 3-NOP has been demonstrated as a highly effective strategy for inhibiting rumen methanogenesis with no negative effects on intake and lactation performance in dairy cows (Haisan et al., 2014, 2017; Hristov et al., 2015b; Melgar et al., 2018b, 2019). In this experiment cows were not blocked according to BW; thus, the lower DMI among 3-NOP cows observed in the current study can be partially explained by the lower overall $\mathrm{BW}$ of the 3 -NOP cows throughout the course of the experiment, which is supported by the 
lack of effect of treatment on DMI when expressed on a $\mathrm{BW}$ basis. It is important to note, however, that 3-NOP cows appeared to gain less weight, although the effect was not statistically significant. In beef cattle, Vyas et al. (2018) reported a 7 and 5\% decrease in DMI when 3-NOP was supplemented during the backgrounding and finishing phases, respectively. In contrast, Melgar et al. (2018a) reported that inclusion of 3-NOP up to $120 \mathrm{mg} / \mathrm{kg}$ of DM had no effect on TMR DMI or palatability in dairy cows.
A decrease in DMI with no effect on MY in dairy cows will improve feed efficiency (Wang et al., 1992). Cows in early lactation support milk production by using body reserves, thus becoming more feed efficient (Grummer, 1995). The increased feed efficiency $(6 \%)$ in the current experiment is the result of a combination of decreased feed intake $(5 \%)$ at similar milk production and potentially greater loss of BW for the 3-NOP cows.

Blaxter and Czerkawski (1966) suggested that reductions in $\mathrm{CH}_{4}$ provide more $\mathrm{ME}$ that can be used for

Table 10. Effect of 3-nitrooxypropanol (3-NOP) on blood plasma AA concentration $(\mu M)$ in early-lactation dairy cows

\begin{tabular}{|c|c|c|c|c|}
\hline \multirow[b]{2}{*}{ Item } & \multicolumn{2}{|c|}{ Treatment $^{1}$} & \multirow[b]{2}{*}{$\mathrm{SEM}^{2}$} & \multirow[b]{2}{*}{$P$-value ${ }^{3}$} \\
\hline & $\mathrm{CON}$ & $3-\mathrm{NOP}$ & & \\
\hline $\operatorname{Arg}$ & 70.5 & 66.2 & 1.50 & 0.03 \\
\hline His & 47.9 & 47.1 & 1.35 & 0.67 \\
\hline Ile & 122 & 114 & 4.86 & 0.25 \\
\hline Leu & 130 & 125 & 4.34 & 0.40 \\
\hline Lys & 75.4 & 70.2 & 2.10 & 0.08 \\
\hline Met & 19.9 & 20.0 & 0.49 & 0.87 \\
\hline Phe & 42.2 & 42.4 & 0.78 & 0.86 \\
\hline Thr & 102 & 101 & 3.29 & 0.93 \\
\hline $\operatorname{Trp}$ & 30.4 & 29.4 & 0.65 & 0.29 \\
\hline Val & 248 & 226 & 8.30 & 0.07 \\
\hline$\Sigma \mathrm{EAA}^{4}$ & 888 & 843 & 22.0 & 0.15 \\
\hline Ala & 260 & 244 & 6.21 & 0.07 \\
\hline Asn & 45.7 & 46.3 & 0.88 & 0.66 \\
\hline Asp & 6.39 & 6.02 & 0.490 & 0.20 \\
\hline Cit & 86.1 & 76.9 & 2.32 & 0.004 \\
\hline Cys & 4.43 & 5.27 & 0.450 & 0.14 \\
\hline Gln & 253 & 257 & 5.89 & 0.53 \\
\hline Glu & 50.4 & 50.6 & 1.91 & 0.87 \\
\hline Gly & 384 & 401 & 12.4 & 0.28 \\
\hline Нyp & 15.2 & 16.1 & 0.53 & 0.14 \\
\hline Orn & 37.8 & 35.4 & 0.92 & 0.07 \\
\hline Pro & 81.4 & 82.6 & 1.72 & 0.62 \\
\hline Ser & 89.4 & 101 & 2.22 & $<0.001$ \\
\hline $\mathrm{Tau}$ & 38.4 & 37.9 & 1.32 & 0.74 \\
\hline Tyr & 42.5 & 42.9 & 1.24 & 0.79 \\
\hline$\Sigma \mathrm{NEAA}^{5}$ & 1,395 & 1,403 & 19.1 & 0.19 \\
\hline TAA & 2,283 & 2,243 & 33.9 & 0.58 \\
\hline Carnosine $^{6}$ & 15.2 & 14.7 & 0.61 & 0.40 \\
\hline Sarcosine $^{7}$ & 14.7 & 21.4 & 1.28 & $<0.001$ \\
\hline $1-\mathrm{MH}^{8}$ & 15.9 & 17.5 & 0.65 & 0.03 \\
\hline $3-\mathrm{MH}$ & 4.29 & 4.57 & 0.215 & 0.27 \\
\hline Phosphoserine & 12.9 & 12.5 & 0.56 & 0.61 \\
\hline$\alpha$-Aminobutyric acid & 21.5 & 22.6 & 1.12 & 0.41 \\
\hline$\alpha$-Amino adipic acid & 10.3 & 8.72 & 0.57 & 0.06 \\
\hline
\end{tabular}

${ }^{1}$ Treatments were control diet (CON) and basal diet plus $60 \mathrm{mg}$ of $3-\mathrm{NOP} / \mathrm{kg}$ of feed DM (3-NOP).

${ }^{2}$ Largest SEM published in table; $\mathrm{n}=168$ ( $\mathrm{n}$ represents number of observations used in the statistical analysis). Data are from 56 cows.

${ }^{3}$ Main effect of treatment. Treatment $\times$ parity (primi- vs. multiparous) interaction, $P>0.10$, except Met, Phe, Ala, Cit, Tau, and Trp $(P \leq 0.05)$. Treatment $\times$ diet (fresh vs. lactating) interaction, $P \geq 0.07$, except phosphoserine $(P=0.04)$. Treatment $\times$ study phase (phase 1 or 2$)$ interaction, $P \geq 0.14$.

${ }^{4}$ Sum of EAA (Arg, His, Ile, Leu, Lys, Met, Phe, Thr, Trp, and Val).

${ }^{5}$ Sum of NEAA (Ala, Asn, Asp, Cys, Cit, Gln, Glu, Gly, Orn, Pro, Ser, Tau, and Tyr were considered as NEAA).

${ }^{6}$ Dipeptide ( $\beta$-alanyl-L-His).

${ }^{7} 2$-(Methylamino) acetic acid.

${ }^{8} \mathrm{MH}=$ methylhistidine. 
Table 11. Effect of 3-nitrooxypropanol (3-NOP) on the resumption of ovarian cyclicity in early-lactation dairy cows

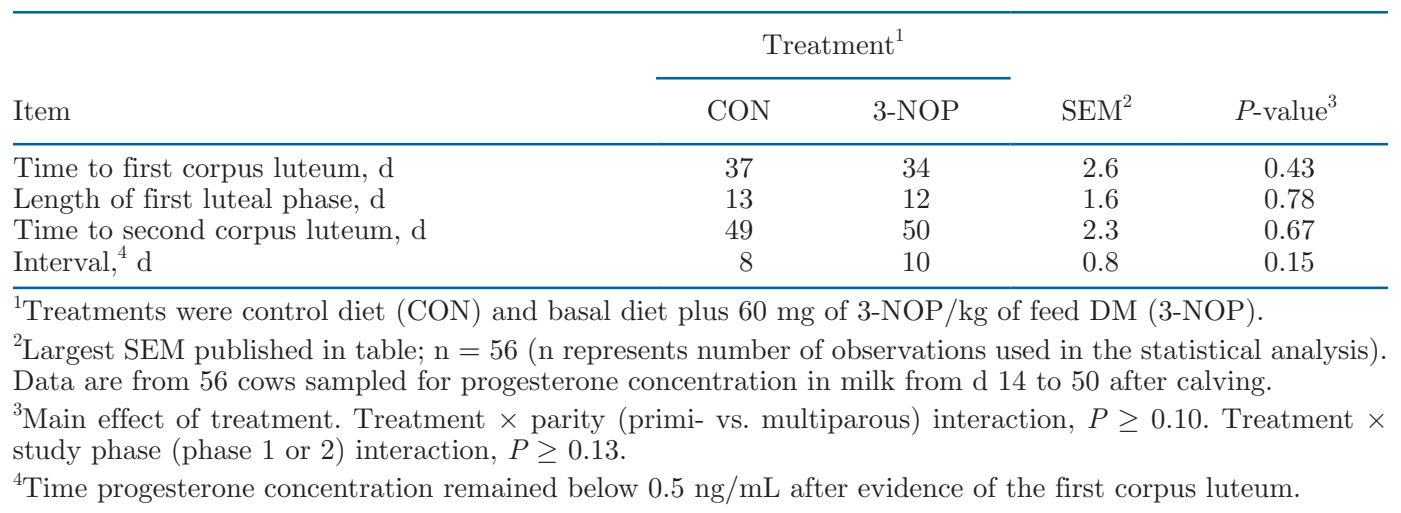

milk production or body tissue gain. However, milk production and weight gain are not always improved in dairy cattle when $\mathrm{CH}_{4}$ is decreased (van Zijderveld et al., 2011). Reynolds et al. (2014) did not observe differences in BW in late-lactation dairy cows when $\mathrm{CH}_{4}$ production was decreased by $7 \%$. In contrast to the current study, 3-NOP has been reported to increase BW in mid-lactation dairy cows (Haisan et al., 2014; Hristov et al., 2015b) and steers (Martinez-Fernandez et al., 2018). Further, an improved feed conversion efficiency of steers fed 3-NOP during the backgrounding and finishing phases was reported by Vyas et al. (2018). Hristov et al. (2015b) estimated that up to $71 \%$ of the increased daily BW gain among the 3-NOP cows could be attributed to decreased $\mathrm{CH}_{4}$ production. Similarly, Haisan et al. (2014) estimated that the reduction in energy loss as $\mathrm{CH}_{4}$ with 3-NOP accounted for $80 \%$ of the increased $\mathrm{BW}$ gain during their experiment. The hypothesis of the current study was that early-lactation cows, experiencing negative energy balance (NRC, 2001), may benefit from decreased feed energy losses as enteric $\mathrm{CH}_{4}$. This expectation, however, was not materialized in BW gain, most likely due to the slightly lower BW of the 3-NOP cows throughout the study.

Contrary to our hypothesis, MY and composition were unaltered by 3-NOP despite the decrease in feed energy lost as $\mathrm{CH}_{4}$. These results agree with previous reports from long-term production studies (Hristov et al., 2015b; Van Wesemael et al., 2019) and short-term experiments (Haisan et al., 2014, 2017; Reynolds et al., 2014; Lopes et al., 2016) in which 3-NOP did not affect lactational performance of dairy cows. Exceptions are the reported increased milk fat yield with 3-NOP by Lopes et al. (2016) and the linear increase in milk fat concentration in a dose-response study by Melgar et al. (2018b). In a recent study by Melgar et al. (2019) with mid-lactation cows, 3-NOP increased milk fat concentration and tended to increase fat yield compared with a control diet. Milk fat concentration may be increased due to increased synthesis of milk FA precursors, such as butyrate, as observed in the current experiment; butyrate is used as an energy source and as a substrate for milk fat synthesis (Black et al., 1961).

It has been shown that shifts in rumen fermentation affect $\mathrm{CH}_{4}$ production (Ellis et al., 2008) and the precursors of de novo synthesis of milk FA (Dijkstra et al., 2011). The observed increased concentration of short-chain FA in milk fat with 3 -NOP is consistent with previous work from our laboratory (Hristov et al., 2015b). In contrast, Reynolds et al. (2014) found no effect of 3-NOP on milk FA when the inhibitor was dosed directly into the rumen, and its mitigation effect was minimal. Short-chain milk FA are synthesized de novo in the mammary gland mainly from acetate and indirectly from butyrate (Dijkstra et al., 2011). Therefore, butyrate is clearly linked to glucose and lipid metabolism (Kleiber et al., 1954; Black et al., 1961) and MY (Seymour et al., 2005). Butyrate synthesized in the rumen is absorbed through the rumen wall and is mostly metabolized by rumen epithelial cells as an energy source or converted into BHB, becoming a source of carbon in the mammary gland, where it can be used as a primer for short-chain milk FA synthesis (Bergman, 1990; Bauman and Griinari, 2003). Thus, the increased concentration of butyrate in ruminal fluid can be linked to the increased concentration of short-chain FA in milk fat. These FA, except 4:0, were positively related to enteric $\mathrm{CH}_{4}$ production in dairy cows in the meta-analysis by Dijkstra et al. (2011). The acetate fermentation pathway in the rumen, primarily responsible for fermentation of fiber, also generates $\mathrm{H}_{2}$ and consequently $\mathrm{CH}_{4}$, which can explain the relationship between de novo synthesized short-chain FA in milk and enteric $\mathrm{CH}_{4}$ observed by Dijkstra et al. (2011). It appears, however, that these relationships do not hold when rumen methanogenesis is suppressed by 3 -NOP, 
or butyrate (and not acetate) becomes the primary substrate for synthesis of short-chain FA in milk.

It is known that some feed additives can affect the organoleptic characteristics of milk and dairy products (Schiano et al., 2017). The current study is the first report on the effects of 3-NOP on the sensory characteristics of bovine milk. The comprehensive panel evaluation concluded that 3-NOP triggered no perceptible changes in the sensory characteristics of milk and cheddar cheese from cows fed 3-NOP.

The increase in MUN when 3-NOP was fed in the current experiment contrasts with earlier reports (Reynolds et al., 2014; Lopes et al., 2016; Haisan et al., 2017) but is consistent with more recent data reported by Melgar et al. (2018b, 2019). In our earlier study, in which graded levels of 3 -NOP (from 0 to $80 \mathrm{mg} / \mathrm{kg}$ of feed DM) were fed, MUN was not statistically different among treatment, although compared with the control, a numerical increase in MUN occurred with the 3 -NOP treatments $(10.9,11.3,12.0$, and $11.3 \mathrm{mg} / \mathrm{dL}$, respectively; $\mathrm{SEM}=0.52 ; P=0.51$; unpublished data from Hristov et al., 2015b). A possible explanation for the current results is the increased digestibility of dietary CP by 3 -NOP; however, the MUN data contrast with the lack of effect of 3-NOP on rumen ammonia, plasma urea, and urinary urea $\mathrm{N}$ concentrations. The relationship between plasma urea $\mathrm{N}$ and MUN in dairy cows is well established (Broderick and Clayton, 1997; Nousiainen et al., 2009), and Huhtanen et al. (2015) reported a reasonable relationship of MUN with rumen ammonia concentration. In contrast with our data and observations from Reynolds et al. (2014) in dairy cattle and Romero-Perez et al. (2014, 2015) in beef cattle, Lopes et al. (2016) reported a decrease in ruminal ammonia concentration associated with $3-\mathrm{NOP}$ in dairy cows. In the study by Lopes et al. (2016), 3-NOP, in fact, decreased rumen ammonia concentration, and in the current experiment ammonia concentration was also numerically lower for 3-NOP. Lopes et al. (2016) suggested that the decrease in ruminal ammonia concentration could be the result of decreased proteolysis or increased ammonia uptake by bacteria in the rumen. The increased MUN in the current experiment does not seem related to increased AA catabolism, based on the lack of effect in essential and nonessential AA concentration in plasma.

The lower DMI with 3-NOP could partially explain the increased CP digestibility for that diet (Tyrrell and Moe, 1975). Reynolds et al. (2014) reported decreased apparent total-tract digestibility of DM, OM, $\mathrm{CP}, \mathrm{NDF}$, and ADF in 3-NOP fed cows. Conversely, Hristov et al. (2015b) observed a quadratic increase in apparent total-tract digestibility of DM, OM, CP, and ADF. Haisan et al. (2017) also reported increased apparent total-tract digestibility for DM and NDF and tendencies for increased $\mathrm{OM}$ and $\mathrm{CP}$ in dairy cows receiving 3-NOP. Disappearance of potentially degradable nutrients (DM, OM, NDF, and $\mathrm{CP}$ ) in the rumen depends on rate of digestion and rate of passage (Allen, 1996). Rate of passage increases with increasing intake (Colucci et al., 1982), but digestibility decreases and total VFA production can also decrease. Total VFA production per $\mathrm{kg}$ DMI and per digestible OM were within the values of 3.0 to $10.3 \mathrm{~mol} / \mathrm{kg}$ of DM in sheep and nonlactating cattle reported by Martin et al. (2001). Among lactating dairy cows given normal and low-roughage diets, Sutton et al. (2003) reported 8.7 and $9.6 \mathrm{~mol} / \mathrm{kg}$ digestible $\mathrm{DM}$, respectively. Overall, the reduction in $\mathrm{CH}_{4}$ production with 3 -NOP did not seem to interfere with nutrient digestion, which is consistent with previous studies (Haisan et al., 2014; Reynolds et al., 2014; Romero-Perez et al., 2014, 2015).

The lower total excretion of $\mathrm{N}$ (in urine and feces) for 3 -NOP in the current experiment can be explained by the numerically lower $\mathrm{N}$ intake compared with $\mathrm{CON}$. As a percent of $\mathrm{N}$ intake, $\mathrm{N}$ excretion in urine was not different between treatments; therefore, the effect of 3-NOP on total $\mathrm{N}$ excretion was due to decreased $\mathrm{N}$ excretion in feces (due to increased digestibility) or to an effect of stage of lactation. In contrast, Reynolds et al. (2014) reported an increase in $\mathrm{N}$ excretion and a reduction in milk $\mathrm{N}$ secretion as percentage of total $\mathrm{N}$ intake in cows fed 3-NOP compared with CON.

Data from blood analyses indicated that adding 3 -NOP to the diet of early-lactation cows did not affect the concentration of common metabolites such as glucose, BUN, NEFA, and BHB. Similar results were reported by Haisan et al. (2017) for mid- to late-lactation dairy cows, except that these authors reported a tendency for increased concentration of glucose in cows fed 3-NOP. Both NEFA and BHB are related to fat mobilization (Roberts et al., 1981), indicative of negative energy balance during the transition period (Ospina et al., 2010), and inversely related to DMI (Bertics et al., 1992). The lack of effect on NEFA and BHB concentrations in the current study is probably related to the relatively similar DMI in relation to $\mathrm{BW}$ of the cows between treatments.

Supplementation of the diet with 3-NOP did not correlate with changes to concentrations of leptin or IGF1 , but was associated with decreased insulin concentration in blood. The difference in insulin was persistent in both fresh and lactation stages of the study. Unlike the results from the current experiment, Haisan et al. (2017) did not observe an effect of 3-NOP on insulin concentration in mid- to late-lactation cows. A review by Oh et al. (2017) speculated that a decrease in serum insulin without an effect on plasma glucose concentra- 
tion may be associated with a positive effect on energy partitioning for production purposes in dairy cows. The decrease in insulin concentration by 3 -NOP in our study may have redirected glucose for milk production by lowering glucose uptake in insulin-dependent tissues as skeletal muscle and adipose tissue, as suggested by De Koster and Opsomer (2013). As a result, the reduction in enteric $\mathrm{CH}_{4}$ emission could have contributed to the improved feed efficiency with 3-NOP at lower DMI. It has been noted that IGF-1 concentration is higher in younger animals (Butler and Smith, 1989; Butler, 2001), which may explain the treatment $\times$ study phase interaction we observed for IGF-1; in experimental phase $2,92 \%$ of the cows were multiparous, whereas $68 \%$ were multiparous in phase 1 .

Compared with the CON cows, 3-NOP exhibited decreased neutrophil count by $8 \%$. Uterine immune defense is associated with peripheral blood neutrophils during early lactation (Hammon et al., 2006). In effect, the lower neutrophil count we observed with 3 -NOP in the current experiment may reflect the shorter immune activity compared with CON cows during early lactation, suggesting that 3 -NOP cows completed uterine involution earlier. Another explanation could be that 3-NOP cows started to cycle earlier than CON cows, thus producing more progesterone sooner, and according to Roth et al. (1983), progesterone may depress other neutrophil functions.

The tendency toward decreased blood hemoglobin observed for the 3-NOP cows may be related to nitrite released during the activation of the 3 -NOP molecule in the rumen. Nitrite, formed in very small amounts inside the cells (archaea) alongside the inactivation of the methyl-coenzyme $\mathrm{M}$ reductase, is a common rumen intermediate (Duin et al., 2016), which is absorbed directly across the rumen wall into the bloodstream and primarily denitrated in the liver. Nitrite in the blood stimulates the conversion of hemoglobin into methemoglobin (Wang et al., 1961), as documented by Olijhoek et al. (2016) when studying the effect of dietary levels of nitrate in dairy cows.

Reduction in the volume of red blood cells was used to explain the decrease in hematocrit by Wohlt et al. (1984) and may explain the decrease in hematocrit in 3-NOP cows in the current experiment. Also, 3-NOP cows had lower BW than did CON cows, and the relationship between plasma volume and volume per unit of BW, in addition to uptake and secretion of water in milk (Wohlt et al., 1984), could influence hematocrit values. The treatment $x$ diet interaction we observed for lymphocytes could be related to the decrease in concentration of lymphocytes during the fresh period. The second phase of the current experiment was from June to December, and summer increases in white and red blood cells counts, hemoglobin, and hematocrit have been reported (Koubkova et al., 2002). This could explain the treatment $\times$ study phase interaction we observed for concentration of white blood cells and lymphocytes, lymphocytes as percentage of total white blood cells, and mean corpuscular hemoglobin in the current study.

Reduction in enteric $\mathrm{CH}_{4}$ emission by 3 -NOP could lead to increased energy availability in dairy cows in mid- to late lactation (Haisan et al., 2014; Hristov et al., 2015b). During early lactation, dairy cows enter a period of negative energy balance; therefore, we hypothesized that the additional net energy provided by decreased methanogenesis would improve resumption of ovarian cyclicity (Staples et al., 1990). As Butler (2005) discussed, the negative energy balance during early lactation influences the luteal functionality of the dairy cow. Delays in resumption of ovarian activity will prolong the calving interval (Wathes et al., 2007), negatively affecting reproductive performance. We found no evidence that 3-NOP altered the number of days to formation of a CL, the length of the first luteal phase, or the time to the second CL. Six of the CON and 3 of the 3-NOP fed cows did not exhibit elevated progesterone concentrations in milk between 14 and $50 \mathrm{~d}$. To our knowledge this is the first study to evaluate the effect of 3 -NOP on resumption of ovarian activity in dairy cows. Considering that lactation is a dynamic metabolic process, more studies (and with more animals) are needed to better understand resumption of ovarian cyclicity under inhibited methanogenesis by $3-\mathrm{NOP}$.

Inhibition of $\mathrm{CH}_{4}$ production in the rumen has the potential to improve energy efficiency (Vyas et al., 2018). Under the experimental conditions of this study, the mean decrease in $\mathrm{CH}_{4}$ emission of $93 \mathrm{~g} / \mathrm{d}$ per cow would translate to $1.21 \mathrm{Mcal} / \mathrm{d}$ per cow (at $0.013 \mathrm{Mcal} / \mathrm{g}$ of $\mathrm{CH}_{4}$ ) of digestible energy not emitted as $\mathrm{CH}_{4}$. If energy in $\mathrm{CH}_{4}$ is converted to $\mathrm{NE}_{\mathrm{L}}$ with efficiency similar to that of dietary digestible energy (NRC, 1981), and we assume no differences in the efficiency of energy use between treatments (and no change in $\mathrm{BW}$ ), the reduction in emitted $\mathrm{CH}_{4}$ with 3 -NOP would represent an additional $0.29 \mathrm{Mcal} / \mathrm{d}$ of $\mathrm{NE}_{\mathrm{L}}$ that can be used for milk synthesis. If $0.74 \mathrm{Mcal} \mathrm{NE}_{\mathrm{L}}$ is required for the synthesis of $1 \mathrm{~kg}$ of milk (NRC, 2001), in theory, the reduction in $\mathrm{CH}_{4}$ emission with 3-NOP would allow the cow to produce an additional $0.39 \mathrm{~kg} / \mathrm{d}$ of milk.

However, consistent with previous experiments among dairy cows (Haisan et al., 2014; Reynolds et al., 2014; Hristov et al., 2015b), no effect of 3-NOP on milk production (or composition) was observed in the current experiment. Haisan et al. (2014) and Hristov et al. (2015b) observed an increase in BW, whereas Reynolds et al. (2014), Haisan et al. (2017), and Mel- 
gar et al. (2019) did not report effects on BW. All these experiments used mid- to late-lactation cows, at which time MY is not an energetic priority, whereas in the current experiment we used early-lactation cows, expecting improved performance in a stage of lactation that is associated with a negative energy balance. The $26 \%$ decrease in $\mathrm{CH}_{4}$ emission, however, did not result in production responses or increased BW gain. Despite this lack of production effects, the increased MY and ECM feed efficiency with 3-NOP does indicate a more efficient use of feed energy for productive purposes when early lactation cows receive 3-NOP.

\section{CONCLUSIONS}

Administration of 3-NOP via the TMR at a concentration of $60 \mathrm{mg} / \mathrm{kg}$ of feed DM decreased daily enteric $\mathrm{CH}_{4}$ emission by $26 \%$ in early-lactation dairy cows. The enteric $\mathrm{CH}_{4}$ yield decreased by $21 \%$, and $\mathrm{CH}_{4}$ emission intensity was decreased by $25 \%$. Dry matter intake was lower in 3-NOP cows (by 5\%), but ECM production was not affected, which resulted in increased ECM feed efficiency compared with CON cows. No difference was observed in DMI as percentage of BW of the cows, suggesting that the decrease in DMI may have been due to the slightly lower BW of 3-NOP cows. Inhibition of rumen methanogenesis decreased the relative proportions of acetate and increased those of butyrate and valerate in ruminal fluid. Concentration of de novo synthesized short-chain FA in milk was increased by 3 -NOP, but treatment had no effect on blood metabolites or plasma AA. Inclusion of 3-NOP did not appear to affect the organoleptic characteristics of milk and cheese made from the milk of cows fed the experimental diet. Overall, results suggest that supplementation with $3-\mathrm{NOP}$ is a promising strategy for reducing enteric $\mathrm{CH}_{4}$ emissions while maintaining production in early-lactation dairy cows, and that it may increase feed efficiency, depending on its effect on DMI. We found no evidence that 3 -NOP affected onset of ovarian activity, although additional studies with greater numbers of animals would be required to more definitively address this question.

\section{ACKNOWLEDGMENTS}

This work was supported by the USDA (Washington, DC) National Institute of Food and Agriculture Federal Appropriations under Project PEN 04539 and Accession Number 1000803. The authors thank DSM Nutritional Products (Basel, Switzerland) for providing partial financial support for the project and for supplying 3-NOP. The authors also thank the staff of The Pennsylvania State University Dairy Teaching and
Research Center (University Park) for their conscientious care and management of the animals and for technical assistance during the study. A. Melgar was supported by the Government of Panama through the IFARHU-SENACYT Scholarship Program (Clayton, City of Knowledge, Panama) and the Agricultural Research Institute of Panama (IDIAP; Clayton, City of Knowledge, Panama).

\section{REFERENCES}

Abecia, L., P. G. Toral, A. I. Martín-García, G. Martínez, N. W. Tomkins, E. Molina-Alcaide, C. J. Newbold, and D. R. Yáñez-Ruiz. 2012. Effect of bromochloromethane on methane emission, rumen fermentation pattern, milk yield, and fatty acid profile in lactating dairy goats. J. Dairy Sci. 95:2027-2036. https://doi.org/10.3168/ jds.2011-4831.

Allen, M. S. 1996. Physical constraints on voluntary intake of forages by ruminants. J. Anim. Sci. 74:3063-3075. https://doi.org/10 $.2527 / 1996.74123063 x$.

Alstrup, L., A. L. F. Hellwing, P. Lund, and M. R. Weisbjerg. 2015 Effect of fat supplementation and stage of lactation on methane production in dairy cows. Anim. Feed Sci. Technol. 207:10-19. https://doi.org/10.1016/j.anifeedsci.2015.05.017.

AOAC International. 2000. Official Methods of Analysis. 17th ed. AOAC International, Arlington, VA.

AOAC International. 2006. Official Methods of Analysis. 18th ed. AOAC International, Arlington, VA.

Bauman, D. E., and J. M. Griinari. 2003. Nutritional regulation of milk fat synthesis. Annu. Rev. Nutr. 23:203-227. https://doi.org/ 10.1146/annurev.nutr.23.011702.073408.

Beever, D. E. 2006. The impact of controlled nutrition during the dry period on dairy cow health, fertility and performance. Anim. Reprod. Sci. 96:212-226. https://doi.org/10.1016/j.anireprosci.2006 .08 .002 .

Bell, A. W. 1995. Regulation of organic nutrient metabolism during transition from late pregnancy to early lactation. J. Anim. Sci. 73:2804-2819.

Bergman, E. N. 1990. Energy contributions of volatile fatty acids from the gastrointestinal tract in various species. Physiol. Rev. 70:567590. https://doi.org/10.1152/physrev.1990.70.2.567.

Bertics, S. J., R. R. Grummer, C. Cadorniga-Valino, and E. E. Stoddard. 1992. Effect of prepartum dry matter intake on liver triglyceride concentration and early lactation. J. Dairy Sci. 75:1914-1922. https://doi.org/10.3168/jds.S0022-0302(92)77951-X.

Black, A. L., M. Kleiber, and A. M. Brown. 1961. Butyrate metabolism in the lactating cow. J. Biol. Chem. 236:2399-2403.

Blaxter, K. L., and J. W. Czerkawski. 1966. Modification of the methane production of the sheep by supplementation of its diet. J. Sci. Food Agric. 17:417-421. https://doi.org/10.1002/jsfa.2740170907.

Broderick, G. A., and M. K. Clayton. 1997. A statistical evaluation of animal and nutritional factors influencing concentrations of milk urea nitrogen. J. Dairy Sci. 80:2964-2971. https://doi.org/10 .3168/jds.S0022-0302(97)76262-3.

Butler, W. R. 2001. Nutritional effects on resumption of ovarian cyclicity and conception rate in postpartum dairy cows. Anim. Sci. Occas. Publ. 26:133-145. https://doi.org/10.1017/S0263967X00033644.

Butler, W. R. 2005. Inhibition of ovulation in the postpartum cow and the lactating sow. Livest. Prod. Sci. 98:5-12. https://doi.org/10 .1016/j.livprodsci.2005.10.007.

Butler, W. R., and R. D. Smith. 1989. Interrelationships between energy balance and postpartum reproductive function in dairy cattle. J. Dairy Sci. 72:767-783. https://doi.org/10.3168/jds.S0022 -0302(89)79169-4.

Chaney, A. L., and E. P. Marbach. 1962. Modified reagents for determination of urea and ammonia. Clin. Chem. 8:130-132. 
Chapelle, F. H., D. A. Vroblesky, J. C. Woodward, and D. R. Lovely. 1997. Practical considerations for measuring hydrogen concentrations in groundwater. Environ. Sci. Technol. 31:2873-2877. https:/ /doi.org/10.1021/es970085c.

Chen, X. B., Y. K. Chen, M. F. Franklin, E. R. Ørskov, and W. J. Shand. 1992. The effect of feed intake and body weight on purine derivative excretion and microbial protein supply in sheep. J. Anim. Sci. 70:1534-1542. https://doi.org/10.2527/1992.7051534x.

Colucci, P. E., L. E. Chase, and P. J. Van Soest. 1982. Feed intake, apparent diet digestibility, and rate of particulate passage in dairy cattle. J. Dairy Sci. 65:1445-1456. https://doi.org/10.3168/jds .S0022-0302(82)82367-9.

CVAS (Cumberland Valley Analytical Services). 2018. Resources: Lab Procedures. Accessed Oct. 16, 2018. http://www.foragelab.com/ Resources/Lab-Procedures/.

De Koster, J. D., and G. Opsomer. 2013. Insulin resistance in dairy cows. Vet. Clin. North Am. Food Anim. Pract. 29:299-322. https: //doi.org/10.1016/j.cvfa.2013.04.002.

Deyl, Z., J. Hyanek, and M. Horakova. 1986. Profiling of amino acids in body fluids and tissues by means of liquid chromatography. J. Chromatogr. 379:177-250. https://doi.org/10.1016/s0378 $-4347(00) 80685-4$.

Dijkstra, J., A. Bannink, J. France, E. Kebreab, and S. van Gastelen. 2018. Short communication: Antimethanogenic effects of 3-nitrooxypropanol depend on supplementation dose, dietary fiber content, and cattle type. J. Dairy Sci. 101:9041-9047. https://doi.org/ $10.3168 / j \mathrm{jds} .2018-14456$.

Dijkstra, J., S. M. van Zijderveld, J. A. Apajalahti, A. Bannink, W. J. J. Gerrits, J. R. Newbold, H. B. Perdok, and H. Berends. 2011. Relationships between methane production and milk fatty acid profiles in dairy cattle. Anim. Feed Sci. Technol. 166-167:590-595. https://doi.org/10.1016/j.anifeedsci.2011.04.042.

Duin, E. C., T. Wagner, S. Shima, D. Prakash, B. Cronin, D. R. Yáñez-Ruiz, S. Duval, R. Rümbeli, R. T. Stemmler, R. K. Thauer, and M. Kindermann. 2016. Mode of action uncovered for the specific reduction of methane emissions from ruminants by the small molecule 3-nitrooxypropanol. Proc. Natl. Acad. Sci. USA 113:6172-6177. https://doi.org/10.1073/pnas.1600298113.

Duval, S., and M. Kindermann. 2012. Use of nitrooxy organic molecules in feed for reducing methane emission in ruminants, and/ or to improve ruminant performance. World Intellectual Property Organization, assignee. Pat. No. WO 2012/084629 A1.

Ellis, J. L., J. Dijkstra, E. Kebread, A. Bannink, N. E. Odongo, B. W. McBride, and J. France. 2008. Aspects of rumen microbiology central to mechanistic modelling of methane production in cattle. J. Agric. Sci. 146:213-233. https://doi.org/10.1017/ S0021859608007752.

Etherington, W. G., K. A. Christie, J. S. Walton, K. E. Leslie, S. Wickstrom, and W. H. Johnson. 1991. Progesterone profiles in postpartum Holstein dairy cows as an aid in the study of retained fetal membranes, pyometra and anestrus. Theriogenology 35:731746. https://doi.org/10.1016/0093-691x(91)90414-9.

Faustini, M., M. Battocchio, D. Vigo, A. Prandi, M. Veronesi, A. Comin, and F. Cairoli. 2007. Pregnancy diagnosis in dairy cows by whey progesterone analysis: An ROC approach. Theriogenology 67:1386-1392. https://doi.org/10.1016/j.theriogenology.2007 .02 .011 .

Fekkes, D. 1996. State-of-the-art of high-performance liquid chromatographic analysis of amino acids in physiological samples. J. Chromatogr. B Biomed. Appl. 682:3-22. https://doi.org/10.1016/0378 $-4347(96) 00057-6$.

Fetter, M. E. 2017. Effects of an extruded flaxseed supplement on transition cow immune function and effects of a methane inhibitor on transition cow ovarian activity. MS Thesis. Department of Animal Sciences, The Pennsylvania State Univ., University Park, PA.

Gerber, P. J., H. Steinfeld, B. Henderson, A. Mottet, C. Opio, J. Dijkman, A. Falcucci, and G. Tempio. 2013. Tackling climate change through livestock: A global assessment of emissions and mitigation opportunities. Food and Agriculture Organization of the United Nations (FAO), Rome, Italy.
Gray, F. V., A. F. Pilgrim, H. J. Rodda, and R. A. Weller. 1952. Nature of origin of the volatile fatty acids in the rumen of sheep. J. Exp. Biol. 29:57-68.

Grummer, R. R. 1995. Impact of changes in organic nutrient metabolism on feeding the transition dairy cow. J. Anim. Sci. 73:28202833. https://doi.org/10.2527/1995.7392820x.

Guyader, J., E. M. Ungerfeld, and K. A. Beauchemin. 2017. Redirection of metabolic hydrogen by inhibiting methanogenesis in the rumen simulation technique (RUSITEC). Front. Microbiol. 8:393. https://doi.org/10.3389/fmicb.2017.00393.

Haisan, J., Y. Sun, L. L. Guan, K. A. Beauchemin, A. Iwaasa, S. Duval, D. R. Barreda, and M. Oba. 2014. The effects of feeding 3-nitrooxypropanol on methane emissions and productivity of Holstein cows in mid lactation. J. Dairy Sci. 97:3110-3119. https://doi.org/ 10.3168/jds.2013-7834.

Haisan, J., Y. Sun, L. L. Guan, K. A. Beauchemin, A. Iwaasa, S. Duval, M. Kindermann, D. R. Barreda, and M. Oba. 2017. The effects of feeding 3-nitrooxypropanol at two doses on milk production, rumen fermentation, plasma metabolites, nutrient digestibility, and methane emissions in lactating Holstein cows. Anim. Prod. Sci. 57:282-289. https://doi.org/10.1071/AN15219.

Hall, M. B. 2009. Determination of starch, including maltooligosaccharides, in animal feeds: Comparison of methods and a method recommended for AOAC collaborative study. J. AOAC Int. 92:42-49.

Hammon, D. S., I. M. Evjen, T. R. Dhiman, J. P. Goff, and J. L. Walters. 2006. Neutrophil function and energy status in Holstein cows with uterine health disorders. Vet. Immunol. Immunopathol. 113:21-29. https://doi.org/10.1016/j.vetimm.2006.03.022.

Hart, K. J., D. R. Yáñez-Ruiz, S. M. Duval, N. R. McEwan, and C J. Newbold. 2008. Plant extracts to manipulate rumen fermentation. Anim. Feed Sci. Technol. 147:8-35. https://doi.org/10.1016/ j.anifeedsci.2007.09.007.

Heinrichs, A., and P. Kononoff. 2002. Evaluating particle size of forages and TMRs using the new Penn State forage particle separator. DAS 02-42. Technical Bulletin of The Pennsylvania State University, College of Agricultural Sciences Cooperative Extension, University Park, PA.

Hristov, A. N. 2007. Comparative characterization of reticular and duodenal digesta and possibilities to estimate microbial outflow from the rumen based on reticular sampling in dairy cows. J. Anim. Sci. 85:2606-2613. https://doi.org/10.2527/jas.2006-852.

Hristov, A. N., and G. Broderick. 1996. Synthesis of microbial protein in ruminally cannulated cows fed alfalfa silage, alfalfa hay or corn silage. J. Dairy Sci. 79:1627-1637. https://doi.org/10.3168/ jds.S0022-0302(96)76526-8.

Hristov, A. N., C. Lee, T. Cassidy, M. Long, B. Corl, and R. Forster. 2011. Effects of lauric and myristic acids on ruminal fermentation, production, and milk fatty acid composition in lactating dairy cows. J. Dairy Sci. 94:382-395. https://doi.org/10.3168/jds.2010 -3508 .

Hristov, A. N., and A. Melgar. 2019. Variability in the relationship between enteric methane emission and dry matter intake in dairy cows. Page 82 in Proc. 7th International Greenhouse Gas and Animal Agriculture Conference, Iguassu Falls, Brazil. A. Berndt, L. G. Pereira Ribeiro, and A. L. Abdala, ed. Embrapa Southeast Livestock, São Carlos, SP, Brazil.

Hristov, A. N., J. Oh, F. Giallongo, T. Frederick, H. Weeks, P. R. Zimmerman, R. A. Hristova, S. R. Zimmerman, and A. F. Branco. 2015a. The use of an automated system (GreenFeed) to monitor enteric methane and carbon dioxide emissions from ruminant animals. J. Vis. Exp. 103:e52904. https://doi.org/10.3791/52904.

Hristov, A. N., J. Oh, F. Giallongo, T. W. Frederick, M. T. Harper, H. L. Weeks, A. F. Branco, P. J. Moate, M. H. Deighton, S. R. O. Williams, M. Kindermann, and S. Duval. 2015b. An inhibitor persistently decreased enteric methane emission from dairy cows with no negative effect on milk production. Proc. Natl. Acad. Sci. USA 112:10663-10668. https://doi.org/10.1073/pnas.1504124112.

Hristov, A. N., J. Oh, C. Lee, R. Meinen, F. Montes, T. Ott, J. Firkins, A. Rotz, C. Dell, A. Adesogan, W. Yang, J. Tricarico, E. Kebreab, G. Waghorn, J. Dijkstra, and S. Oosting. 2013. Mitigation of greenhouse gas emissions in livestock production: A review 
of technical options for non- $\mathrm{CO}_{2}$ emissions. Food and Agriculture Organization of the United Nations (FAO), Animal Production and Health Paper No. 177. P. J. Gerber, B. Henderson, and H. P. S. Makkar, ed. FAO, Rome, Italy.

Huhtanen, P., E. H. Cabezas-Garcia, S. J. Krizsan, and K. J. Shingfield. 2015. Evaluation of between-cow variation in milk urea and rumen ammonia nitrogen concentrations and the association with nitrogen utilization and diet digestibility in lactating cows. J. Dairy Sci. 98:3182-3196. https://doi.org/10.3168/jds.2014-8215.

Huhtanen, P., K. Kaustell, and S. Jaakkola. 1994. The use of internal markers to predict total digestibility and duodenal flow of nutrients in cattle given six different diets. Anim. Feed Sci. Technol. 48:211-227. https://doi.org/10.1016/0377-8401(94)90173-2.

Hungate, R. E. 1967. Hydrogen as an intermediate in the rumen fermentation. Arch. Mikrobiol. 59:158-164. https://doi.org/10.1007/ BF00406327.

Hungate, R. E., W. Smith, T. Bauchop, I. Yu, and J. C. Rabinowitz. 1970. Formate as an intermediate in the bovine rumen fermentation. J. Bacteriol. 102:389-397.

Immig, I. 1996. The rumen and hindgut as source of ruminant methanogenesis. Environ. Monit. Assess. 42:57-72. https://doi.org/10 $1007 /$ BF00394042.

Janssen, P. H. 2010. Influence of hydrogen on rumen methane formation and fermentation balances through microbial growth kinetics and fermentation thermodynamics. Anim. Feed Sci. Technol. 160:1-22. https://doi.org/10.1016/j.anifeedsci.2010.07.002.

Johnson, K. A., and D. E. Johnson. 1995. Methane emissions from cattle. J. Anim. Sci. 73:2483-2492. https://doi.org/10.2527/1995 $.7382483 x$.

Kleiber, M., A. L. Black, M. A. Brown, J. Luick, C. F. Baxter, and B. M. Tolbert. 1954. Butyrate as a precursor for milk constituents in the intact dairy cow. J. Biol. Chem. 210:239-247.

Koubkova, M., I. Knizkova, P. Kune, H. Hartlova, J. Flusser, and O. Dolezal. 2002. Influence of high environmental temperatures and evaporative cooling on some physiological, hematological and biochemical parameters in high-yielding dairy cows. Czech J. Anim. Sci. 47:309-318.

Lamming, G. E., and A. O. Darwash. 1998. The use of milk progesterone profiles to characterize components of subfertility in milked dairy cows. Anim. Reprod. Sci. 52:175-190. https://doi.org/10 .1016/S0378-4320(98)00099-2.

Lee, C., A. N. Hristov, T. W. Cassidy, K. S. Heyler, H. Lapierre, G. A. Varga, M. J. de Veth, R. A. Patton, and C. Parys. 2012. Rumenprotected lysine, methionine, and histidine increase milk protein yield in dairy cows fed a metabolizable protein-deficient diet. J. Dairy Sci. 95:6042-6056. https://doi.org/10.3168/jds.2012-5581.

Lopes, J. C., L. F. de Matos, M. T. Harper, F. Giallongo, J. Oh, D. Gruen, S. Ono, M. Kindermann, S. Duval, and A. N. Hristov. 2016. Effect of 3-nitrooxypropanol on methane and hydrogen emissions, methane isotopic signature, and ruminal fermentation in dairy cows. J. Dairy Sci. 99:5335-5344. https://doi.org/10.3168/jds.2015 -10832 .

Martin, C., N. B. Kristensen, and P. Huhtanen. 2001. Comparison of non-tracer and tracer methods for determination of volatile fatty acid production rate in the rumen of sheep fed at two levels of intake. Br. J. Nutr. 86:331-340. https://doi.org/10.1079/ bjn2001386.

Martinez-Fernandez, G., S. Duval, M. Kindermann, H. J. Schirra, S. E. Denman, and C. S. McSweeney. 2018. 3-NOP vs. halogenated compound: Methane production, ruminal fermentation and microbial community response in forage fed cattle. Front. Microbiol. 9:1582. https://doi.org/10.3389/fmicb.2018.01582.

Marty, R. J., and D. J. Demeyer. 1973. The effect of inhibitors of methane production on fermentation pattern and stoichiometry in vitro using rumen contents from sheep given molasses. Br. J. Nutr. 30:369-376. https://doi.org/10.1079/bjn19730041.

McAllister, T. A., and C. J. Newbold. 2008. Redirecting rumen fermentation to reduce methanogenesis. Aust. J. Exp. Agric. 48:7-13. https://doi.org/10.1071/EA07218.

Melgar, A., C. F. A. Lage, K. Nedelkov, S. E. Räisänen, H. Stefenoni, M. E. Young, X. Chen, J. Oh, S. Duval, M. Kindermann, N. D.
Walker, and A. N. Hristov. 2019. Effects of 3-nitrooxypropanol on enteric methane emission and lactational performance of dairy cows. J. Dairy Sci. 102(E-Suppl. 1):428 (Abstr.).

Melgar, A., K. Nedelkov, C. M. M. R. Martins, K. C. Welter, X. Chen, M. T. Harper, S. Duval, and A. N. Hristov. 2018a. Palatability of total mixed rations containing 3-nitrooxypropanol for lactating dairy cows. J. Dairy Sci. 101(E-Suppl. 2):92 (Abstr.).

Melgar, A., K. C. Welter, K. Nedelkov, C. M. M. R. Martins, M. T. Harper, J. Oh, S. E. Räisänen, X. Chen, S. F. Cueva, S. Duval, and A. N. Hristov. 2018b. Dose-response effect of 3-nitrooxypropanol on enteric methane emission in dairy cows. J. Dairy Sci. 101(E-Suppl. 2):198 (Abstr.).

Morgavi, D. P., E. Forano, C. Martin, and C. J. Newbold. 2010. Microbial ecosystem and methanogenesis in ruminants. Animal 4:10241036. https://doi.org/10.1017/S1751731110000546.

Morrison, M., and R. I. Mackie. 1996. Nitrogen metabolism by ruminal microorganisms: Current understanding and future perspectives. Aust. J. Agric. Res. 47:227-246. https://doi.org/10.1071/ AR9960227.

Munro, C., and G. Stabenfeldt. 1984. Development of a microtiter plate enzyme immunoassay for the determination of progesterone. J. Endocrinol. 101:41-49. https://doi.org/10.1677/joe.0.1010041.

National Research Council. 1981. Nutritional Energetics of Domestic Animals and Glossary of Energy Terms. Natl. Acad. Sci., Washington, DC.

National Research Council. 2001. Nutrient Requirements of Dairy Cattle. 7th rev. ed. Natl. Acad. Press., Washington, DC.

Nebel, R. L., and M. L. McGilliard. 1993. Interactions of high milk yield and reproductive performance in dairy cows. J. Dairy Sci. 76:3257-3268. https://doi.org/10.3168/jds.S0022-0302(93)77662 -6 .

Nousiainen, J., M. Rinne, and P. Huhtanen. 2009. A meta-analysis of feed digestion in dairy cows. 1 . The effects of forage and concentrate factors on total diet digestibility. J. Dairy Sci. 92:5019-5030. https://doi.org/10.3168/jds.2008-1833.

Oh, J., A. N. Hristov, C. Lee, T. Cassidy, K. Heyler, G. A. Varga, J. Pate, S. Walusimbi, E. Brzezicka, K. Toyokawa, J. Werner, S. S. Donkin, R. Elias, S. Dowd, and D. Bravo. 2013. Immune and production responses of dairy cows to postruminal supplementation with phytonutrients. J. Dairy Sci. 96:7830-7843. https://doi.org/ 10.3168/jds.2013-7089

Oh, J., E. H. Wall, D. M. Bravo, and A. N. Hristov. 2017. Host-mediated effects of phytonutrients in ruminants: A review. J. Dairy Sci. 100:5974-5983. https://doi.org/10.3168/jds.2016-12341.

Olijhoek, D. W., A. L. F. Hellwing, M. Brask, M. R. Weisbjerg, O. Højberg, M. K. Larsen, J. Dijkstra, E. J. Erlandsen, and P. Lund. 2016. Effect of dietary nitrate level on enteric methane production, hydrogen emission, rumen fermentation, and nutrient digestibility in dairy cows. J. Dairy Sci. 99:6191-6205. https://doi.org/10 $.3168 /$ jds.2015-10691.

Ospina, P. A., D. V. Nydam, T. Stokol, and T. R. Overton. 2010. Associations of elevated nonesterified fatty acids and beta-hydroxybutyrate concentrations with early lactation reproductive performance and milk production in transition dairy cattle in the northeastern United States. J. Dairy Sci. 93:1596-1603. https:// doi.org/10.3168/jds.2009-2852.

Penner, G. B., J. R. Aschenbach, G. Gabel, R. Rackwitz, and M. Oba 2009. Epithelial capacity for apical uptake of short chain fatty acids is a key determinant for intraruminal $\mathrm{pH}$ and the susceptibility to subacute ruminal acidosis in sheep. J. Nutr. 139:1714-1720. https://doi.org/10.3945/jn.109.108506.

Reynolds, C. K., D. J. Humphries, P. Kirton, M. Kindermann, S. Duval, and W. Steinberg. 2014. Effects of 3-nitrooxypropanol on methane emission, digestion, and energy and nitrogen balance of lactating dairy cows. J. Dairy Sci. 97:3777-3789. https://doi.org/ 10.3168/jds.2013-7397.

Rico, D. E., and K. J. Harvatine. 2013. Induction of and recovery from milk fat depression occurs progressively in dairy cows switched between diets that differ in fiber and oil concentration. J. Dairy Sci. 96:6621-6630. https://doi.org/10.3168/jds.2013-6820. 
Roberts, C. J., I. M. Reid, G. J. Rowlands, and A. Patterson. 1981. A fat mobilization syndrome in dairy cows in early lactation. Vet. Rec. 108:7-9. https://doi.org/10.1136/vr.108.1.7.

Romero-Perez, A., E. K. Okine, S. M. McGinn, L. L. Guan, M. Oba, S. M. Duval, M. Kindermann, and K. A. Beauchemin. 2014. The potential of 3-nitrooxypropanol to lower enteric methane emissions from beef cattle. J. Anim. Sci. 92:4682-4693. https://doi.org/10 $.2527 /$ jas.2014-7573.

Romero-Perez, A., E. K. Okine, S. M. McGinn, L. L. Guan, M. Oba, S. M. Duval, M. Kindermann, and K. A. Beauchemin. 2015. Sustained reduction in methane production from long-term addition of 3-nitrooxypropanol to a beef cattle diet. J. Anim. Sci. 93:17801791. https://doi.org/10.2527/jas.2014-8726.

Roth, J. A., M. L. Kaeberle, L. H. Appell, and R. F. Nachreiner. 1983. Association of increased estradiol and progesterone blood values with altered bovine polymorphonuclear leukocyte function. Am. J. Vet. Res. 44:247-253.

Russell, J. B. 2002. Rumen Microbiology and its Role in Ruminant Nutrition. 1st ed. James B. Russell Publishing Co., Ithaca, New York.

Schiano, A. N., W. S. Harwood, and M. A. Drake. 2017. A 100-year review: Sensory analysis of milk. J. Dairy Sci. 100:9966-9986. https: //doi.org/10.3168/jds.2017-13031.

Schneider, B. H., and W. P. Flatt. 1975. The Evaluation of Feeds Through Digestibility Experiments. University of Georgia Press, Athens, GA.

Seymour, W. M., D. R. Campbell, and Z. B. Johnson. 2005. Relationships between rumen volatile fatty acid concentrations and milk production in dairy cows: A literature study. Anim. Feed Sci. Technol. 119:155-169. https://doi.org/10.1016/j.anifeedsci.2004 .10 .001 .

Sjaunja, L. O., L. Baevre, L. Junkkarinen, J. Pedersen, and J. Setälä. 1990. A Nordic proposal for an energy corrected milk (ECM) formula. Pages 156-157 in 27th Session of the International Commission for Breeding and Productivity of Milk Animals, Paris, France. Wageningen Academic Publishers, Wageningen, the Netherlands.

Soliva, C. R., S. L. Amelchanka, S. M. Duval, and M. Kreuzer. 2011. Ruminal methane inhibition potential of various pure compounds in comparison with garlic oil as determined with a rumen simulation technique (Rusitec). Br. J. Nutr. 106:114-122. https://doi .org/10.1017/S0007114510005684.

Staples, C. R., W. W. Thatcher, and J. H. Clark. 1990. Relationship between ovarian activity and energy status during the early postpartum period of high producing dairy cows. J. Dairy Sci. 73:938-947. https://doi.org/10.3168/jds.S0022-0302(90)78750-4.

Sutton, J. D., M. S. Dhanoa, S. V. Morant, J. France, D. J. Napper, and E. Schuller. 2003. Rates of production of acetate, propionate, and butyrate in the rumen of lactating dairy cows given normal and low-roughage diets. J. Dairy Sci. 86:3620-3633. https://doi .org/10.3168/jds.S0022-0302(03)73968-X.

Taylor, V. J., D. E. Beever, M. J. Bryant, and D. C. Wathes. 2004. First lactation ovarian function in dairy heifers in relation to prepubertal metabolic profiles. J. Endocrinol. 180:63-75.

Trei, J. E., G. C. Scott, and R. C. Parish. 1972. Influence of methane inhibition on energetic efficiency of lambs. J. Anim. Sci. 34:510 515. https://doi.org/10.2527/jas1972.343510x.

Tyrrell, H. F., and P. W. Moe. 1975. Effect of intake on digestive efficiency. J. Dairy Sci. 58:1151-1163. https://doi.org/10.3168/jds .S0022-0302(75)84694-7.

Ungerfeld, E. M. 2015. Shifts in metabolic hydrogen sinks in the methanogenesis inhibited ruminal fermentation: A meta-analysis. Front. Microbiol. 6:37. https://doi.org/10.3389/fmicb.2015.00037.
Ungerfeld, E. M. 2018. Inhibition of rumen methanogenesis and ruminant productivity: A meta-analysis. Front. Vet. Sci. 5:113. https:/ /doi.org/10.3389/fvets.2018.00113.

van Lingen, H. J., C. M. Plugge, J. G. Fadel, E. Kebreab, A. Bannink, and J. Dijkstra. 2016. Thermodynamic driving force of hydrogen on rumen microbial metabolism: A theoretical investigation. PLoS One 11:e0161362. https://doi.org/10.1371/journal.pone.0161362.

Van Soest, P. J., J. B. Robertson, and B. A. Lewis. 1991. Methods for dietary fiber, neutral detergent fiber, and nonstarch polysaccharides in relation to animal nutrition. J. Dairy Sci. 74:3583-3597. https://doi.org/10.3168/jds.S0022-0302(91)78551-2.

Van Wesemael, D., L. Vandaele, B. Ampe, H. Cattrysse, S. Duval, M. Kindermann, V. Fievez, S. De Campeneere, and N. Peiren. 2019 Reducing enteric methane emissions from dairy cattle: Two ways to supplement 3-nitrooxypropanol. J. Dairy Sci. 102:1780-1787. https://doi.org/10.3168/jds.2018-14534.

van Zijderveld, S. M., W. J. J. Gerrits, J. Dijkstra, J. R. Newbold, R. B. A. Hulshof, and H. B. Perdok. 2011. Persistency of methane mitigation by dietary nitrate supplementation in dairy cows. J. Dairy Sci. 94:4028-4038. https://doi.org/10.3168/jds.2011-4236.

Vyas, D., A. W. Alemu, S. M. McGinn, S. M. Duval, M. Kindermann, and K. A. Beauchemin. 2018. The combined effects of supplementing monensin and 3-nitrooxypropanol on methane emissions, growth rate, and feed conversion efficiency in beef cattle fed high forage and high grain diets. J. Anim. Sci. 96:2923-2938. https:// doi.org/10.1093/jas/sky174.

Wang, L. C., J. Garcia-Rivera, and R. H. Burris. 1961. Metabolism of nitrate by cattle. Biochem. J. 81:237.

Wang, S., G. L. Roy, A. J. Lee, A. J. McAllister, T. R. Batra, C. Y. Lin, J. A. Vesely, J. M. Wauthy, and K. A. Winter. 1992. Evaluation of various measures of and factors influencing feed efficiency of dairy cattle. J. Dairy Sci. 75:1273-1280. https://doi.org/10 .3168/jds.S0022-0302(92)77877-1.

Wathes, D. C., N. Bourne, Z. Cheng, G. E. Mann, V. J. Taylor, and M. P. Coffey. 2007. Multiple correlation analyses of metabolic and endocrine profiles with fertility in primiparous and multiparous cows. J. Dairy Sci. 90:1310-1325. https://doi.org/10.3168/jds .S0022-0302(07)71619-3.

Wildman, E. E., G. M. Jones, P. E. Wagner, R. L. Boman, H. F. Troutt Jr., and T. N. Lesch. 1982. A dairy cow body condition scoring system and its relationship to standard production characteristics. J. Dairy Sci. 65:495-501. https://doi.org/10.3168/jds .S0022-0302(82)82223-6.

Wohlt, J. E., J. L. Evans, and J. R. Trout. 1984. Blood constituents in lactating Holstein cows influenced by hematocrit, sampling site, and diet protein and calcium. J. Dairy Sci. 67:2236-2246. https:// doi.org/10.3168/jds.S0022-0302(84)81571-4.

Wolin, M. J. 1981. Fermentation in the rumen and human large intestine. Science 213:1463-1468. https://doi.org/10.1126/science .7280665 .

Wolin, M. J., T. L. Miller, and C. S. Stewart. 1997. Microbe-microbe interactions. Pages 467-491 in The Rumen Microbial Ecosystem. P. N. Hobson and C. S. Stewart, ed. Blackie Academic and Professional, London, UK. https://doi.org/10.1007/978-94-009-1453-7 $-11$.

Yang, C. M., and G. A. Varga. 1989. Effect of three concentrate feeding frequencies on rumen protozoa, rumen digesta kinetics, and milk yield in dairy cows. J. Dairy Sci. 72:950-957. https://doi.org/ 10.3168/jds.S0022-0302(89)79188-8. 